\title{
Ensayos normativos para la caracterización de patologías en pizarras para cubiertas
}

\section{Standard tests for the characterization of roofing slate pathologies}

\author{
$\underline{\text { V. Cárdenes }}^{(*)}$, F. J. Mateos ${ }^{(*)}$, A. Rubio-Ordóñez ${ }^{(*)}$, C. Monterroso(**)
}

Recepción/Received: 22-XI-10

Aceptación/Accepted: 10-X-11

Publicado online/Online publishing: 23-XII-11

\section{RESUMEN}

Las patologías que se originan en pizarra para cubiertas son debidas fundamentalmente a la presencia de materiales alterables (sulfuros de hierro, carbonatos y materia orgánica). Estos minerales pueden llegar a alterarse por efecto de los agentes medioambientales, una vez que la pizarra es puesta en obra. Las patologías están principalmente asociadas a procesos de oxidación y yesificación de las citadas fases minerales. En este trabajo se determinan las patologías potenciales de varias pizarras para cubiertas españolas, utilizando los ensayos definidos en las normas UNE-EN 12326:2005, 14147:2004 y 11597:2007.

Palabras clave: pizarras cubiertas, oxidación, yesificación, patología; alteración.

\section{SUMMARY}

The pathologies formed in slate roofs are mainly due to the presence of potentially unstable minerals (iron sulfides, carbonates and organic matter). These minerals may become altered by the effect of environmental agents, once the slate roof is finished. The pathologies are mainly associated with oxidation and gypsification processes of the cited mineral phases. In this work, the potential pathologies of several Spanish roofing slates are identified, using the tests defined in the European Norms EN 12326:2005, 14147:2004 and 11597:2007.

Keywords: roofing slate, oxidation, gypsification, pathologies.

\section{INTRODUCCIÓN}

La pizarra para cubiertas puede desarrollar una serie de patologías, entre las cuales las más importantes por frecuencia e impacto negativo son la oxidación y la

\section{INTRODUCTION}

As a building material, there are several different pathologies that may affect roofing slate, among which the most important, in terms of their negative impact

\footnotetext{
(*) Universidad de Oviedo.

(**) Universidade de Santiago de Compostela (A Coruña, España). 
yesificación. Ambas patologías están íntimamente relacionadas con la presencia de minerales susceptibles a la alteración química, como son sulfuros de hierro, carbonatos y materia orgánica, los cuales pueden alterarse en respuesta a nuevas condiciones medioambientales al ser colocada la pizarra en la cubierta. La oxidación $(1,2)$ produce regueros de óxido sobre la superficie de la cubierta, lo que impide clasificar pizarras con abundancia de sulfuros de hierro como producto de primera clase comercial, a pesar de que el resto de sus propiedades físico-mecánicas (fisibilidad, resistencia a la flexión, absorción de agua, etc.) sean óptimas. La oxidabilidad de los sulfuros de hierro depende de la especie mineral y grado de cristalización de los mismos (3). Por el contrario, la yesificación puede llegar a afectar la cohesión interna de la placa, debido al crecimiento de cristales de yeso entre las láminas de filosilicatos que forman la pizarra, por lo que potencialmente es más dañina que la oxidación. El mayor porcentaje de reclamaciones recibidas por parte de las empresas productoras (Figura 1) corresponde a cambios cromáticos producidos por oxidaciones y yesificaciones, seguido de lejos por las pérdidas y ganancias de masa. Además, durante la producción en cantera, los niveles que presentan elevadas concentraciones de minerales alterables no llegan a ser aprovechados, vertiéndose directamente a las escombreras y produciéndose una importante pérdida económica y un fuerte agravamiento del impacto ambiental generado por el incremento de las escombreras de pizarra $(4,5)$.

\section{PATOLOGÍAS EN PIZARRAS PARA CUBIERTAS}

Las alteraciones que se pueden desarrollar en pizarras para cubiertas se dividen en tres grandes grupos (Tabla 1), teniendo en cuenta los criterios dictados desde el ICOMOS (6) para la clasificación de patologías en rocas ornamentales y patrimonio histórico. and frequency, are oxidation and gypsification. Both pathologies are closely related to the presence of minerals prone to chemical alteration, such as iron sulfides and organic matter (oxidation), and carbonates (gypsification), which may react with environmental elements (sun, rain, atmospheric pollutants, etc.) once a slate roofing tile has been put in place. The oxidation of iron sulfides $(1,2)$ produces reddish rust marks on the surface of the slate; as such, slates that contain these minerals cannot be classified as top quality commercial products, even if the rest of their physical and mechanical properties (fissility, flexural strength, water absorption, etc.) are optimal. Oxidation of iron sulfides is a factor of the mineral phases and their crystallization grade (3). Gypsification, on the other hand, may affect the inner cohesion of the slate tiles, due to the growth of gypsum crystals between the phyllosilicate sheets that make up the slate, making it more harmful than oxidation. The majority of the complaints received by production companies (Figure 1) have to do with chromatic changes produced by oxidation and gypsification, closely followed by increase and decrease in mass. Also, during the quarrying process, levels with high concentrations of alterable minerals are dumped directly into the tailings, which not only substantially hinders the performance ratio, but also sharply worsens the environmental impact of slate mine tailings $(4,5)$.

\section{PATHOLOGIES IN SLATE ROOFING}

Pathologies that may develop in slate roofs are divided into three groups (Table 1), classified according to the criteria laid out by ICOMOS (6) for pathologies and historical heritage.

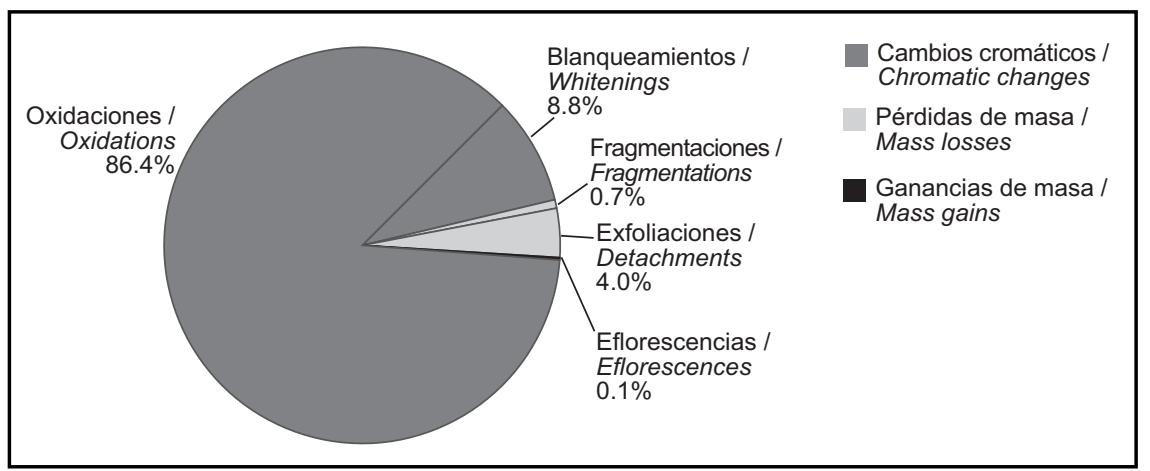

Figura 1. Coste económico porcentual de las reclamaciones causadas por patologías en una empresa productora para el periodo 2003-2007. Datos: elaboración propia.

Figure 1. Economic costs (in \%) of litigations originated by the slate pathologies for a producing company for the period 2003-2007. Data: personal compilation. 
Tabla 1 / Table 1

Patologías más frecuentes en pizarras para cubiertas. Most common pathologies on roofing slates.

\begin{tabular}{|c|c|c|c|}
\hline & Agente / Agent & Mecanismo / Mechanism & Patología / Patology \\
\hline Pérdidas de masa / Mass losses & $\begin{array}{l}\text { Condiciones climáticas naturales, } \\
\text { atmósfera ácida / Climatic } \\
\text { environment, acid atmosphere }\end{array}$ & $\begin{array}{l}\text { Exfoliación mecánica (gelifracción) } \\
\text { o química (nuevas fases minerales), } \\
\text { cambios de temperatura, roturas } \\
\text { a favor de diaclasas / } \\
\text { Mechanical (gelifraction) or chemical } \\
\text { detachment(growing of new mineral } \\
\text { phases), temperature changes }\end{array}$ & $\begin{array}{l}\text { - Exfoliaciones / - Detachments } \\
\text { - Fragmentaciones / } \\
\text { - Fragmentations }\end{array}$ \\
\hline Ganancias de masa / Mass gains & $\begin{array}{c}\text { Contaminación atmosférica, } \\
\text { agentes biológicos / Air pollution, } \\
\text { biological agents }\end{array}$ & $\begin{array}{c}\text { Formación de nuevas fases minerales, } \\
\text { colonias de plantas y líquenes / } \\
\text { Growing of new mineral phases, lichen } \\
\text { and plants colony }\end{array}$ & $\begin{array}{c}\text { - Eflorescencias / - Eflorescences } \\
\text { - Colonizaciones biológicas / } \\
\text { - Biological colony }\end{array}$ \\
\hline $\begin{array}{c}\text { Cambios cromáticos / } \\
\text { Chromatic changes }\end{array}$ & $\begin{array}{c}\text { Atmósfera ácida o salina, } \\
\text { elementos de la cubierta / } \\
\text { Acid or salt atmosphere, roof } \\
\text { elements }\end{array}$ & $\begin{array}{l}\text { Oxidación de sulfuros de hierro, } \\
\text { yesificación de carbonatos, alteración } \\
\text { de otros elementos de la cubierta / } \\
\text { Iron sulfides oxidation, carbonate } \\
\text { gypsification, alteration of roof } \\
\text { elements }\end{array}$ & $\begin{array}{c}\text { - Oxidación / - Oxidation } \\
\text { - Blanqueamiento / - Whitening }\end{array}$ \\
\hline
\end{tabular}

\subsection{Pérdidas de masa}

Las pérdidas de masa se clasifican en dos grupos: exfoliaciones y fragmentaciones. Esta clasificación se hace en función de la relación que guardan con el plano de pizarrosidad (Figura 2).

\subsection{Decrease in mass}

Decrease in mass can be classified into two groups, detachment and fragmentation, based on the relationship with the slaty cleavage planes (Figure 2).

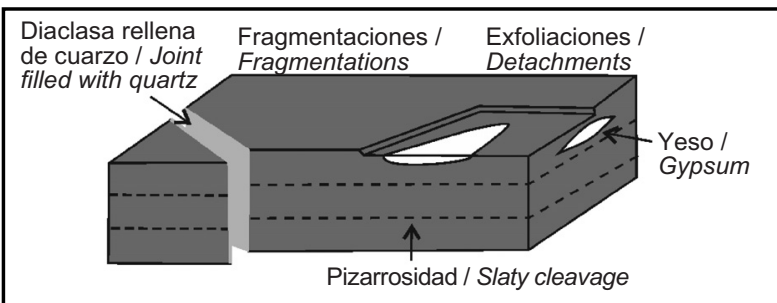

Figura 2. Representación esquemática de las relaciones entre las fragmentaciones y exfoliaciones con la dirección de pizarrosidad. Figure 2. Schematic representation of the relationships between fragmentations and detachments with the slaty cleavage direction.

\section{Exfoliaciones}

Las exfoliaciones son disgregaciones de la pizarra a favor del plano de pizarrosidad. Entre estos planos crecen nuevas fases cristalinas que ocupan mayor volumen, lo que rompe la cohesión interna de la pizarra. Estas fases cristalinas se pueden generar por dos mecanismos principales, yesificación (Figura 3a) y congelación (Figura 3b). La yesificación consiste en la reacción [1] de los carbonatos con sulfatos procedente de la descomposición de los sulfuros de la propia pizarra, o más frecuentemente, de la deposición de contaminantes atmosféricos (7).

\section{Detachment}

Detachment occurs when the slate splits along the slaty cleavage plane. Between these planes new mineral phases grow, occupying a greater volume and breaking the inner cohesion of the slate tile. There are two main mechanisms that produce these new mineral phases: gypsification (Figure 3a) and freezing (Figure 3b). Gypsification consists of the chemical reaction [1] between carbonates and sulphates resulting from the decomposition of the slate sulphides, or more frequently, from the decomposition of atmospheric pollutants (7).

$$
\mathrm{H}_{2} \mathrm{SO}_{4}+\mathrm{CaCO}_{3} \rightarrow \mathrm{CaSO}_{4} \cdot \mathrm{H}_{2} \mathrm{O}+\mathrm{CO}_{2}
$$

El agua intersticial de la pizarra se congela con temperaturas ligeramente inferiores a $0{ }^{\circ} \mathrm{C}$, debido a la inercia
Interstitial water in slate freezes at temperatures slightly below $0^{\circ} \mathrm{C}$, due to the thermal inertia of the slate. The 
térmica de la pizarra. La cantidad de hielo que se formará depende de la capacidad de absorción de agua. Las pizarras para cubiertas españolas poseen unos valores de absorción de agua muy bajos, inferiores al 0,6\% (1), lo que hace que sean relativamente resistentes frente a la congelación (8).

\section{Fragmentaciones}

El otro tipo de pérdidas de masa que se produce son las fragmentaciones o roturas de la placa de pizarra. A diferencia de las exfoliaciones, estas se producen perpendicularmente al plano de pizarrosidad. Estas roturas se deben a diaclasas rellenas de cuarzo de espesor micrométrico y longitud métrica (Figura $3 \mathrm{c}$ ), conocidas como "pelos" entre los mineros. Si durante el proceso productivo no se evitan estas diaclasas, las placas resultantes acabarán fragmentándose una vez colocadas en la cubierta. Cualquier cambio de temperatura que sufra la pizarra favorecerá la rotura, como por ejemplo el incremento de temperatura por incidencia directa de la luz solar, que puede ser muy rápido, al ser la pizarra un cuerpo oscuro.

Ocasionalmente, la oxidación y desaparición total de los sulfuros de hierro existentes también puede producir exfoliaciones o fragmentaciones, al ser el tamaño del sulfuro total amount of ice formed depends on the stone's water absorption capacity, which in Spanish roofing slate is very low, i.e. less than $0.6 \%$ (1), making Spanish slate relatively resistant to freezing (8).

\section{Fragmentation}

The other type of decrease in mass is fragmentation or breakage of the slate tile. As opposed to detachment, in fragmentation mass decreases due to cracks that form in the plane perpendicular to the slaty cleavage, which have micrometric thickness but considerable length, easily reaching several meters (Figure 3c). They are caused by joints (known as "hairs" among the slate workers) filled with recrystallizations of quartz. If during the slate production process these joints are not avoided, the resulting tiles will eventually break once placed on the roof. Any change in temperature that the slate undergoes could cause it to break, such as the temperature increase caused by direct exposure to sunlight, which can happen very quickly given the darkness and mass of slate.

Occasionally, oxidation and the total disappearance of iron sulphides may also produce detachment or fragmentation, if the size of the iron sulphide is larger

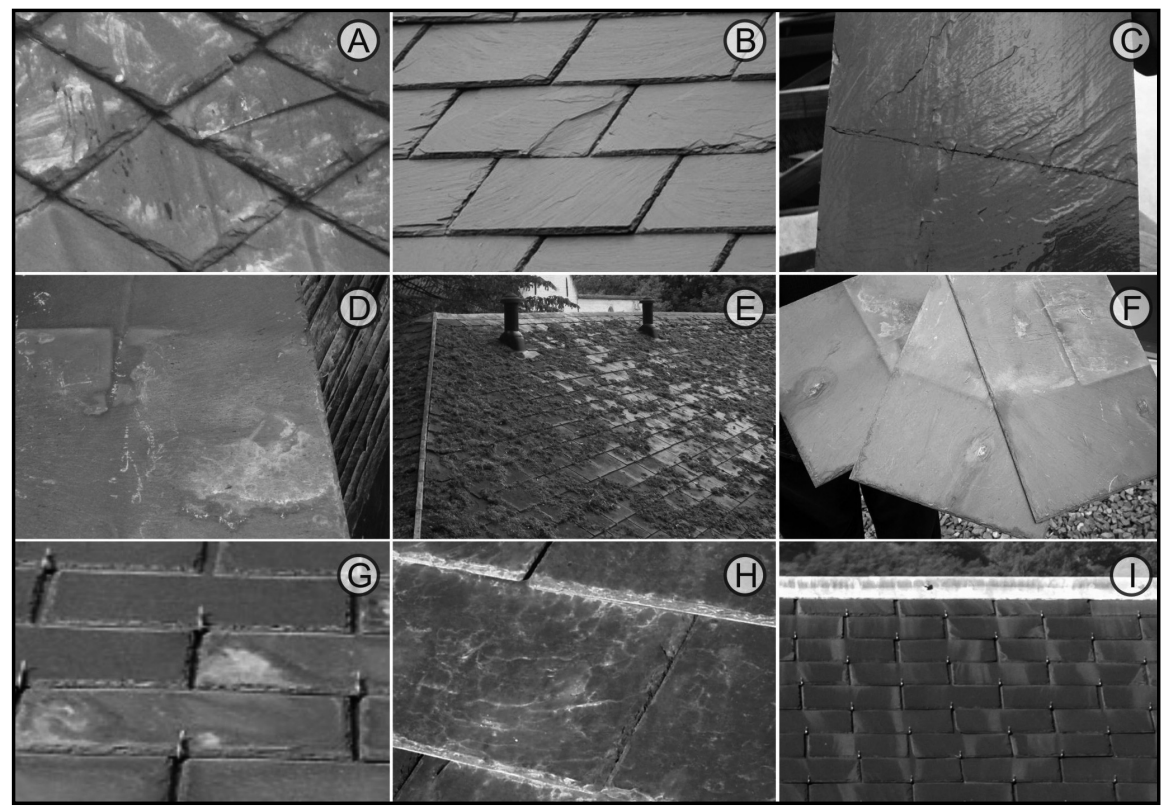

Figura 3. Macrofotografías de distintos tipos de alteraciones en pizarras para cubiertas: 3A Oxidaciones, fragmentaciones y exfoliaciones producidas por yesificación y oxidación de sulfuros de hierro. 3B Exfoliaciones causadas por gelifracción. 3C Zona de fragmentación potencial a favor de una diaclasa rellena de cuarzo ("pelo"). 3D Eflorescencias sobre la superficie de una placa de pizarra. 3E Colonización biológica por musgo. 3F Oxidaciones. 3G Oxidaciones en obra. 3H Blanqueamiento por yesificación. 3I Alteración cromática producida por una cumbrera de aluminio.

Figure 3. Macro images of different types of alterations on roofing slates: $3 A$ Oxidations, fragmentations and detachments produced by gypsification and iron sulfides oxidation. 3B Detachments caused by gelifraction. $3 C$ Potential fragmentation zone following a Joint

filled with Quartz ("hair"). 3D Eflorescences on the surface of a slate tile. 3E Biological colonization by moss. 3F Oxidations. 3G

Oxidations of work in progress. $3 \mathrm{H}$ Whitening induced by gypsification. $3 \mathrm{I}$ Chromatic alteration produced by an aluminium ridge. 
de hierro superior al espesor de la placa de pizarra. Al igual que en el caso de las diaclasas, esta patología se puede prevenir durante el proceso productivo de las placas de pizarra.

\subsection{Ganancias de masa}

Las patologías generadas por ganancias de masa que se pueden encontrar en pizarras son de poca importancia desde un punto de vista económico. Estas patologías suelen surgir varios años después de colocada la pizarra en obra. Se pueden distinguir dos tipos: eflorescencias y colonizaciones biológicas. Las eflorescencias son depósitos de carbonatos sobre la superficie de la pizarra que no llegan a producir exfoliaciones (Figura 3d). Estos crecimientos se producen en ambientes con valores de $\mathrm{pH}$ superiores a $6 \mathrm{y}$ con pocos o nulos contaminantes ambientales, lo que favorece la formación de eflorescencias en lugar de yesificación. Las colonizaciones biológicas son crecimientos de líquenes o musgos sobre la superficie de la placa de pizarra (Figura 3e). Si estos crecimientos llegan a introducirse entre el solape de las placas de pizarra, pueden favorecer la entrada de agua por capilaridad entre las mismas, perdiéndose parcial o totalmente la estanqueidad de la cubierta.

\subsection{Alteraciones cromáticas}

Los cambios de color en pizarras para cubiertas se deben principalmente a la alteración de los sulfuros de hierro y los carbonatos. Los sulfuros de hierro forman un grupo de minerales constituidos mayoritariamente por distintas proporciones de $\mathrm{Fe}$ y $\mathrm{S}$ junto con otros elementos como el Zn, As o Cu. La estructura cristalina del mineral determina la alterabilidad del mismo $(9,10)$. Los dos sulfuros de hierro más comunes en las pizarras para cubiertas son pirita y pirrotina. La pirita tiene estructura cristalográfica cúbica y colores metálicos brillantes y amarillentos, presentándose en cubos o formas rectangulares, lo que permite identificarla con bastante claridad en muestra de mano, mientras que la pirrotina posee estructura hexagonal, presentando hábito amorfo y colores más oscuros. La pirrotina puede aparecer como cristales diagenéticos (11), provenientes de la materia orgánica de los organismos que poblaban la cuenca de sedimentación primigenia, o bien como relleno de moldes de braquiópodos y bivalvos u otro tipo de fauna (12). En las mismas condiciones ambientales, la pirrotina es más alterable que la pirita (3). La presencia de materia orgánica es también perjudicial, ya que su oxidación acidifica el medio, con lo que se incrementa la tasa de oxidación de los sulfuros de hierro $(13,14)$. La oxidación de estos minerales produce por lo general regueros de color rojo-anaranjado (Figuras $3 f$ y $3 g$ ) sobre la superficie de la placa de pizarra.

El otro grupo de minerales potencialmente alterables son los carbonatos, que en las pizarras para cubiertas suelen than the thickness of the slate tile. As for the joints, this pathology may be prevented during the production process.

\subsection{Increase in mass}

Pathologies generated by an increase in the mass of roofing slate are of little importance in economic terms, as they tend arise many years after the roof has been put in place. Increase in mass can be divided into two types: efflorescence and biological colonization. Efflorescence is the growth of carbonates and sulphates on the surface of the tiles, without detachment or flaking (Figure 3d). These growths occur in weak acid environments with little or no environmental pollutants, such that it does not entail gypsification. Biological colonization is the growth of lichen and moss on the surface of the slate (Figure 3e). In some cases, when these growths are able to penetrate between the slate tiles, they open the way for water to get in between the tiles, causing the roof to lose all or part of its watertightness.

\subsection{Color change}

Color change in roofing slate is mainly caused by the alteration of iron sulfides and carbonates. Iron sulfides are a group of minerals made up mainly of different proportions of $\mathrm{Fe}$ and $\mathrm{S}$ along with other elements such as $\mathrm{Zn}$, As and $\mathrm{Cu}$. The crystal structure of the mineral determines its proneness to weathering $(9,10)$. The two most common iron sulfides found in roofing slate are pyrite and pyrrhotite. Pyrite has a cubic structure and bright-yellow metallic color, forming cubes or rectangular shapes, which make it clearly identifiable in hand sample. Pyrrhotite, on the other hand, has a hexagonal structure, with an irregular shape and darker colors, often filling molds of bivalves or other fauna. Pyrrhotite usually occurs as diagenetic crystals (11), formed from the organic matter of organisms that once lived in the original sedimentation basin, or as the filling of brachiopod sand bivalve molds, or other types of fauna (12). Under the same environmental conditions, pyrrhotite is more prone to weathering than pyrite (3). The presence of organic matter also increases proneness to weathering, since its oxidation under atmospheric conditions acidifies the medium, increasing the rates of oxidation of iron sulfides $(13,14)$. The oxidation of these minerals usually produces reddish rust marks (Figures $3 f$ and $3 g$ ) on the surface of the slate tile.

The other group of potentially alterable minerals is carbonates, which in roofing slates are usually found in 
ser ankerita y calcita (15). La alterabilidad de la calcita es superior a la de la ankerita en las mismas condiciones ambientales. Estos carbonatos se pueden encontrar bien como cristales microscópicos, generalmente rellenando huecos en la matriz de la pizarra, bien como nódulos centimétricos (fragmentos de caliza) o vetas micrométricas, al igual que las diaclasas rellenas de cuarzo mencionadas anteriormente. En condiciones ambientales favorables se pueden producir crecimientos y lixiviados sobre la placa de pizarra, adquiriendo esta un color blanquecino característico (Figura 3h) debido a la yesificación de los carbonatos.

Por otra parte, los elementos de la cubierta, como chimeneas, ganchos o claraboyas, pueden producir importantes decoloraciones sobre la cubierta de pizarra debido a su propia oxidación (Figura 3i).

\section{METODOLOGÍA}

\subsection{Muestreo}

Se pueden diferenciar 12 distritos pizarreros en la Península Ibérica (16), aunque la mayor producción se concentra en el Sinclinal de Truchas (17), en el noroeste peninsular. Desde un punto de vista estratigráfico, casi la totalidad de los afloramientos se localizan en el Ordovícico Medio-Superior (18, 19). Para este trabajo se recogieron 4 variedades de pizarra para cubiertas (Tabla 2, Figura 4), dos de ellas en distintas zonas del Sinclinal de Truchas y las otras dos fuera de esta estructura. Se escogieron pizarras con problemas de alterabilidad conocidos, con altos contenidos relativos de sulfuros de hierro (MOR, ALS) y carbonatos (FNS, GON). Las muestras fueron recogidas directamente en cantera. the form of ankerite and calcite (15). Weatherability for calcite is higher than for ankerite under equal environmental conditions. These carbonates can be found either as microscopic crystals, generally filling gaps in the slate matrix, or as centimetric nodules, (fragments of limestone). Under certain environmental conditions, carbonates may cause the slate to whiten (Figure 3h).

In addition, as other elements on the roof wear, such as chimneys or slate hooks and hips, they may pass on significant discoloration to the slate tiles (Figure 3i).

\section{METHODOLOGY}

\subsection{Sampling}

There are 12 distinct mining districts in the Iberian Peninsula (16), although most of the production is concentrated in the districts located in the Truchas Syncline (17), in Northwest Spain. From a stratigraphic point of view, almost all the outcrops are located in the Middle-Superior Ordovician $(18,19)$. For this study, four commercial varieties of slate were collected directly at their respective quarries (Table 2, Figure 4), two of them in different areas of the Truchas Syncline, and the other two from outside this structure. Slates with known weatherability problems were choosen, with high contents of iron sulphides (MOR, ALS) and carbonates (FNS, GON). All slates were directly sampled at their respective quarries.

Tabla 2 / Table 2

Muestras de pizarra empleadas en el trabajo. Slate samples used in this work.

\begin{tabular}{|c|c|c|c|c|}
\hline & FNS & GON & ALS & MOR \\
\hline $\begin{array}{l}\text { Nombre comercial / } \\
\text { Commercial name }\end{array}$ & Pizarra de Fonsagrada & Pizarra de La Baña & Pizarra de Aliste & Pizarra Mormeau \\
\hline $\begin{array}{c}\text { Empresa comercializadora / } \\
\text { Company }\end{array}$ & Europizarras S.A. & Pizarras GONTA & Pizarras Abejeda & CAPIMOR \\
\hline Descripción / Description & $\begin{array}{l}\text { Pizarra gris oscuro / } \\
\text { Dark grey slate }\end{array}$ & $\begin{array}{l}\text { Pizarra gris, grano grueso / } \\
\text { Grey slate, coarse grain }\end{array}$ & $\begin{array}{c}\text { Pizarra negra, abundantes } \\
\text { sulfuros de hierro / Black slate } \\
\text { with abundant iron sulfides }\end{array}$ & $\begin{array}{c}\text { Pizarra gris oscuro, piritas } \\
\text { cúbicas / Dark-grey slate, } \\
\text { cubir pyrites }\end{array}$ \\
\hline $\begin{array}{l}\text { Localización geográfica / } \\
\text { Geographical location }\end{array}$ & A Fonsagrada (Lugo) & La Baña (León) & Aliste (Zamora) & Casaio (Valdeorras) \\
\hline $\begin{array}{l}\text { Nivel estratigráfico / } \\
\text { Stratigraphic level }\end{array}$ & $\begin{array}{c}\text { Formación pizarras de Luarca / } \\
\text { Luarca slates Formation }\end{array}$ & $\begin{array}{l}\text { Formación Rozadais / } \\
\text { Rozadais Formation }\end{array}$ & $\begin{array}{c}\text { Formación pizarras de Luarca / } \\
\text { Luarca slates Formation }\end{array}$ & $\begin{array}{l}\text { Formación pizarras de Luarca / } \\
\text { Luarca slates Formation }\end{array}$ \\
\hline Edad / Age & $\begin{array}{l}\text { Ordovícico Medio-Superior / } \\
\text { Middle-upper Ordovician }\end{array}$ & $\begin{array}{c}\text { Ordovícico superior / Upper } \\
\text { Ordovician }\end{array}$ & $\begin{array}{l}\text { Ordovícico Medio-Superior / } \\
\text { Middle-upper Ordovician }\end{array}$ & $\begin{array}{l}\text { Ordovícico Medio-Superior / } \\
\text { Middle-upper Ordovician }\end{array}$ \\
\hline
\end{tabular}




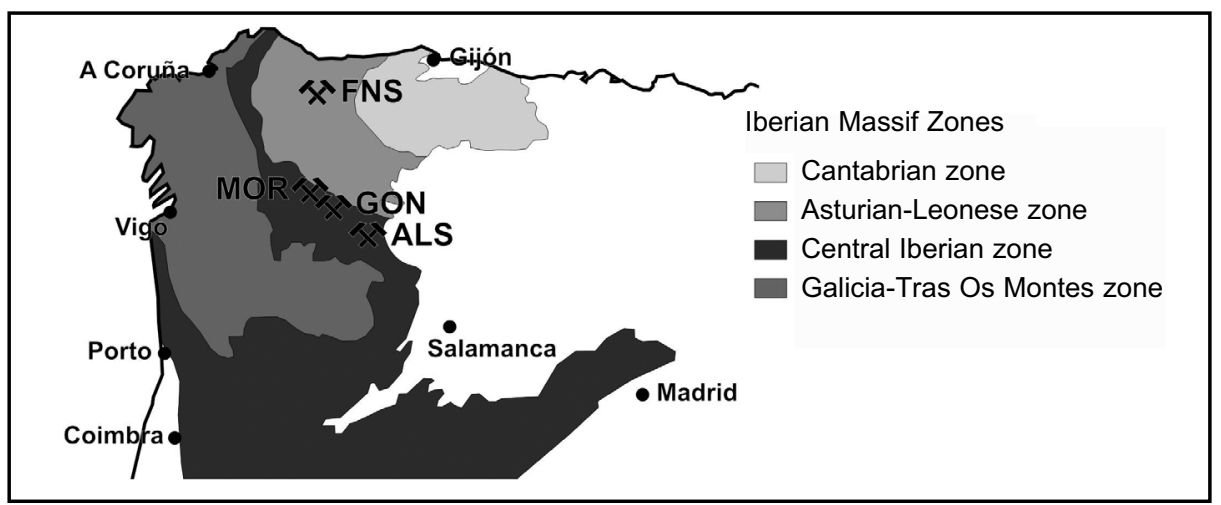

Figura 4. Situación geográfica y geológica de las muestras de pizarra para cubiertas empleadas en el trabajo. Figure 4. Geographical and geological locations of the slate samples used in this work.

\subsection{Caracterización petrológica, química y mineralógica}

La caracterización de las pizarras seleccionadas se realizó mediante las técnicas clásicas de análisis petrológico, como son el estudio con microscopio óptico petrográfico (POL) y electrónico (SEM), difracción de rayos $X$ (DRX), fluorescencia de rayos X (FRX), y la cuantificación del C, $S$ y carbono no carbonatado mediante descomposición térmica catalítica (LECO). El estudio petrográfico puso especial atención en la textura, tamaño, abundancia y morfología de los componentes alterables presentes (sulfuros de hierro, carbonatos y materia orgánica), complementándose las observaciones de POL con las llevadas a cabo en el SEM (microscopio JEOL JSM-6100) con un analizador EDX acoplado. El análisis mineralógico de las muestras se llevó a cabo mediante microanálisis realizados con EDX, determinándose así composiciones elementales puntuales tanto de minerales propios de la pizarra como de los productos de alteración resultantes después de los ensayos. Esta caracterización se completó con análisis DRX, utilizando un equipo Philips PW 1830 con cátodo de $\mathrm{Cu}$ y longitud de onda $\mathrm{K} \alpha=1,54051$, desde $3^{\circ}$ a $65^{\circ} 2 \theta$. La determinación cualitativa y semicuantitativa de las fases minerales resultantes se realizó utilizando el software Xpowder, versión 2010. Los análisis FRX para determinar las composiciones elementales se ejecutaron con un espectrómetro Philips PW-1404 con cátodo de Sc-Mo, con una temperatura de calcinación de $1.050^{\circ} \mathrm{C}$. Los contenidos en carbonatos, carbono no carbonatado y azufre se calcularon mediante descomposición térmica catalítica con un analizador LECO CS-200.

\subsection{Ensayos normativos de alterabilidad}

En la actualidad existen varios ensayos normativos enfocados a cuantificar las patologías de pizarras para cubiertas. La Norma EN 12326:2005 $(20,21)$ "Productos de pizarra y piedra natural para tejados y revestimientos discontinuos" propone distintos ensayos de alterabilidad específicos para los sulfuros de hierro y los carbonatos,

\subsection{Petrological, mineralogical and chemical characterization}

The slate samples were characterized using standard petrographical analysis techniques, such as electronic microprobe (SEM), X-ray diffraction (XRD), X-ray fluorescence $(X R F)$, the study of thin sections with a petrographic microscope (POL), and quantification of $C$, $S$ and non-carbonate carbon through thermal catalytic decomposition (LECO). The petrographic study paid special attention to the texture, size, abundance and morphology of the alterable components that were present (iron sulfides, carbonates and organic matter), complementing the observations of POL with a study carried using SEM (JEOL JSM-6100 microscope), equipped with an EDX analyzer. Mineralogical analyses of samples were performed with EDX, determining the precise elemental compositions of the slate minerals and the alteration products resulting from the weatherability tests. This characterization was completed with XRD analysis, using a Philips PW 1830 instrument with a Cu cathode and a wavelength of $K \alpha=1.54051$, with an angular run from 30 to $65^{\circ} 2 \theta$. Qualitative and semiquantitative determination of the resulting mineral phases was performed with the program Xpowder. To determine the elemental compositions, XRF analyses were performed using a Philips PW-1404 spectrometer with an Sc-Mo cathode, having previously calcinated the sample at $1,050{ }^{\circ} \mathrm{C}$. Carbonate content, non-carbonate carbon and sulfur were calculated by thermal catalytic decomposition, using a LECO CS-200 analyzer.

\subsection{Standard weathering tests}

There are currently several standard tests focused on identifying and quantifying pathologies in roofing slate. European Standard EN 12326:2005 (20, 21), Slate and natural stone for discontinuous roofing and cladding, defines different tests for the alteration of iron sulfides and carbonates, such as thermal cycling tests and 
como son los ensayos de ciclo térmico y exposición al dióxido de azufre $\left(\mathrm{SO}_{2}\right)$, similar este último al ensayo ASTM C-217 (22). Además, esta norma contempla dos series de ensayos de caracterización dirigidos a cuantificar la abundancia de carbonato y materia orgánica (carbono no carbonatado) mediante descomposición térmica catalítica.

Existen otros ensayos normativos que pueden emplearse para determinar y cuantificar la alterabilidad de la pizarra, como son EN 14147:2004 "Determinación de la resistencia al envejecimiento por niebla salina" (23) y EN 11507:2007 "Exposición a lámparas de UV fluorescente y al agua" (24), siendo está última una norma enfocada a pinturas y barnices, pero que puede utilizarse para evaluar los cambios de color producidos en las pizarras mediante radiación UV.

Para determinar las tasas de alteración de las pizarras seleccionadas se recurrió a los ensayos normativos específicos para pizarras para cubiertas y otras rocas, como son el ciclo térmico y la exposición al $\mathrm{SO}_{2}$ según EN 12326:2005, y el ataque por niebla salina según EN 14147:2004. Para comprobar los cambios en los parámetros cromáticos, se expusieron las pizarras a radiación UV tomando como referencia EN 11507:2007. Se utilizaron 3 placas por cada ensayo.

\section{Norma EN 12326:2005 Ciclo térmico y exposición al $\mathrm{SO}_{2}$}

El ciclo térmico según EN 12326:2005 tiene dos etapas bien diferenciadas, una primera de hidratación en la que las placas se sumergen en agua destilada a $\left(23^{\circ} \mathrm{C} \pm 5\right)$ durante 6 horas, y una segunda de deshidratación en la cual las placas se introducen en estufa ventilada a $\left(110^{\circ} \mathrm{C} \pm 5\right)$ durante 17 horas, con una etapa de enfriamiento posterior de una hora. En total, cada ciclo dura 24 horas.

El mecanismo por el cual los sulfuros de hierro se oxidan durante este ensayo se basa en dos factores principales, aporte de $\mathrm{O}_{2}$ y temperatura. Durante la etapa de calentamiento se alcanza la temperatura de $110^{\circ} \mathrm{C}$, perdiendo los sulfuros de hierro el agua que pudiera encontrarse adsorbida en su superficie o en fracturas microscópicas. Este aumento de temperatura hace que el hierro se movilice, desligándose de la estructura del sulfuro de hierro, con lo que aumenta la cantidad de $\mathrm{Fe}^{2+}$ presente en el medio. El paso de $\mathrm{Fe}^{2+}$ a $\mathrm{Fe}^{3+}$ se ve favorecido por el aporte de $\mathrm{O}_{2}$. Con la inmersión en agua destilada y posterior secado en estufa ventilada se asegura un aporte continuo de $\mathrm{O}_{2}$. La disponibilidad de $\mathrm{O}_{2}$ y la temperatura juegan distintos papeles en el proceso de oxidación de los sulfuros de hierro. La presencia de $\mathrm{O}_{2}$ libera el $\mathrm{Fe}^{2+}$, mientras que la temperatura actúa de catalizadora de la reacción. Al comienzo de cada ciclo, exposure to sulfur dioxide $\left(\mathrm{SO}_{2}\right)$, respectively, the latter of which is similar to the US standard ASTM C - 217 (22). Moreover, EN 12326:2005 includes two characterization tests aimed at quantifying the abundance of carbonate and organic matter (represented by non-carbonated carbon) through thermal catalytic decomposition.

There are other standard tests that can be used to identify and quantify the weathering of slate, such as EN 14147:2004, Determination of resistance to ageing by salt mist (23), and EN 11507:2007, Exposure to fluorescent UV and water (24), the latter of which, though focused on paints and varnishes, can still be used to assess changes in color in roofing slate due to UV radiation.

To determine the weathering rates of the slate samples selected for this study, specific tests for roofing slates and other rocks were used, such as thermal cycling and exposure to $\mathrm{SO}_{2}$ as in EN 12326:2005, and attack by salt spray as in EN 14147:2004. To quantify the color variations, slate samples were exposed to UV radiation as in EN 11507:2007. 3 slate samples were used in each test.

\section{EN 12326:2005 Thermal cycle and exposure to $\mathrm{SO}_{2}$}

The thermal cycle described in EN 12326:2005 has two different stages: a first stage of hydration in which the slate tiles are immersed in distilled water $\left(23^{\circ} \mathrm{C} \pm 5\right)$ for 6 hours, and a second stage of dehydration in which tiles are placed inside a ventilated oven $\left(110^{\circ} \mathrm{C} \pm 5\right)$ for 17 hours, and a final cooling stage of 1 hour. In total, each cycle lasts 24 hours.

The mechanism by which iron sulfides are oxidized during this test is based on two main factors, temperature and the release of $\mathrm{O}_{2}$. During the heating stage the temperature of dehydration for iron sulfides is reached $\left(110^{\circ} \mathrm{C}\right)$, at which point these minerals loosing any water adsorbed through the surface or microscopic fractures. This temperature increase causes iron mobilization, dissociating the structure of iron sulfide and increasing the amount of $\mathrm{Fe}^{2+}$ present in the environment. The change of $\mathrm{Fe}^{2+}$ into $\mathrm{Fe}^{3+}$ is favored by the presence of $\mathrm{O}_{2}$. Immersion in distilled water and drying in a ventilated oven ensures a continuous supply of $\mathrm{O}_{2}$. These two factors (an abundance of $\mathrm{O}_{2}$ and an increase in temperature) each exert a different sort of influence over the oxidation process, since on the one hand the presence of $\mathrm{O}_{2}$ releases the $\mathrm{Fe}^{2+}$, while on the other the temperature increase is favorable for this 
durante la fase de hidratación vuelve a adherirse agua a la superficie del sulfuro de hierro. La posterior salida de esta agua origina más $\mathrm{Fe}^{2+}$ libre, con lo que se repite el ciclo de oxidación (10). Después de 20 ciclos se evalúa de manera visual los niveles de oxidación presentes en la superficie de las placas de pizarra, asignándoseles código T1, T2 o T3 en función del grado de oxidación.

En el ensayo de exposición al $\mathrm{SO}_{2}$ según EN 12326:2005, la norma contempla el ataque de las pizarras en dos disoluciones de $\mathrm{H}_{2} \mathrm{SO}_{3}$, una débil y otra fuerte. Las concentraciones molares de estas dos disoluciones son $2 \mathrm{M}$ y $7 \mathrm{M}$, respectivamente. En este trabajo se empleó únicamente la disolución fuerte $7 \mathrm{M}$. Se introdujeron las pizarras previamente secadas hasta masa constante en un recipiente hermético de $20 \mathrm{I}$ de volumen con $600 \mathrm{ml}$ de la disolución $7 \mathrm{M}$ de $\mathrm{H}_{2} \mathrm{SO}_{3}$, durante 21 días, al término de los cuales se extrajeron las pizarras, dejándose secar durante 24 horas y evaluando después su grado de alteración.

Durante el tiempo que las pizarras están en la atmósfera sulfurosa, el $\mathrm{Ca}^{2+}$ de los carbonatos reacciona con el $\mathrm{H}_{2} \mathrm{SO}_{3}$ para dar lugar a yeso, $\mathrm{CaSO}_{4} \cdot 2 \mathrm{H}_{2} \mathrm{O}$, que se deposita sobre la superficie de la pizarra y entre los planos de pizarrosidad. Estos últimos depósitos son los que comprometen la cohesión de las placas de pizarra. Al igual que en el ciclo térmico, la evaluación de los daños generados consiste en asignar al final del ensayo un código visual en función del grado de alteración a las probetas S1 (sin alterar), S2 o S3 (completamente alterada).

\section{Norma EN 14147:2004 Determinación del envejecimiento por niebla salina}

La resistencia al envejecimiento mediante niebla salina según UNE-EN 14147:2004 no se utiliza habitualmente en pizarras para cubiertas, pero sí en otros tipos de piedra, como el granito. Este ensayo aplicado en pizarra para cubiertas produce la oxidación acelerada de los sulfuros de hierro debido a que la solución salina aporta el electrolito de fondo que acelera el intercambio electrónico entre el $\mathrm{Fe}^{2+}$ y $\mathrm{Fe}^{3+}$. Además, el ensayo reproduce las condiciones medioambientales que puede haber en zonas costeras, como la Bretaña francesa y Normandía, regiones donde se utiliza mucha pizarra en las cubiertas. Se introdujeron las probetas en una cámara salina que nebuliza una disolución al $10 \%$ de $\mathrm{NaCl}$ en agua destilada a $(35 \pm 5){ }^{\circ} \mathrm{C}$ durante 4 horas. Pasado este tiempo, se secan las probetas en la misma cámara durante 8 horas a $(35 \pm 5)^{\circ} \mathrm{C}$, constituyendo estos dos pasos un reaction to occur. At the beginning of a new cycle, during the hydration stage, water once again adheres to the surface of the iron sulfides. The subsequent release of this water during the dehydration stage causes more release of $\mathrm{Fe}^{2+}$, thus repeating the cycle of oxidation (10). After 20 cycles, oxidation marks on the slate tile surfaces are visually examined, and assigned one of three codes: T1, T2 and T3, according to the level of oxidation. Using $X R D$, we characterized the alteration products newly formed with the surface oxidation of the iron sulfide, and sampled these alterations by scratching the surface.

The EN 12326:2005 exposure to $\mathrm{SO}_{2}$ test is performed by biting the slate tiles with two solutions of $\mathrm{H}_{2} \mathrm{SO}_{3}$ (one "weak" and one "strong"), which creates a sulfurous atmosphere. The molar concentrations of these two solutions are $2 M$ and $7 M$, respectively. However, in this study we used only the strong $7 M$ solution. Slate tiles, previously dried to a constant mass, were placed inside a 20 liter air-tight container with $600 \mathrm{ml}$ of $7 \mathrm{M} \mathrm{H}_{2} \mathrm{SO}_{3}$ solution for 21 days, after which the tiles were removed and dried for 24 hours, after which their degree of alteration was examined.

During the time that the slate tiles are in the sulfurous atmosphere, the $\mathrm{Ca}^{+}$from the carbonates reacts with the $\mathrm{H}_{2} \mathrm{SO}_{3}$ to produce gypsum $\left(\mathrm{CaSO}_{4} \cdot 2 \mathrm{H}_{2} \mathrm{O}\right)$, which forms deposits on the surface and between the slaty planes of the tiles that jeopardize the cohesion of the slate tiles. As in the thermal cycle, once the test is complete, the weathering of the slate is assessed visually, and is then quantified in each case by assigning one of three codes, S1, S2 or S3, from no weathering to severe weathering.

\section{EN 14147:2004 Determining resistance to aging by salt mist}

EN 14147:2004's test for resistance to aging by salt mist is not commonly used for roofing slates, but is very common in other types of stone like granite. This test, when applied to roofing slate, produces accelerated oxidation of iron sulfides, as salt mist provides a background electrolyte that accelerates the electron exchange between $\mathrm{Fe}^{2+}$ and $\mathrm{Fe}^{3+}$. In addition, this test reproduces the environmental conditions of coastal areas such as Brittany and Normandy, were slate roofs are very popular. Slate tiles were placed inside a chamber that nebulized a saline solution of $10 \% \mathrm{NaCl}$ in distilled water $(35 \pm 5){ }^{\circ} \mathrm{C}$ for four hours. After this time, the slate tiles were dried in the same chamber for eight hours $(35 \pm 5)^{\circ} \mathrm{C}$. These two stages constitute one cycle. The test consists of 60 cycles, at the end of which the samples are weighed to check the weight losses, and 
ciclo. El ensayo se compone de 60 ciclos, al final de los cuales se pesan las probetas, comprobando las posibles pérdidas de peso, y se inspeccionan de manera visual, indicando las descamaciones, roturas, agrietamientos u oxidaciones que pudieran presentar.

\section{Norma EN 11507:2007 Exposición a los rayos UV}

Para medir la resistencia de las pizarras frente a la acción de los rayos UV según EN 11507:2007, se expusieron estas a la radiación ultravioleta procedente de una lámpara Philips HPR 125W HG, con una emisión máxima entre 300 y $400 \mathrm{~nm}$, situada a una distancia de $50 \mathrm{~cm}$ en una cámara cerrada durante 1.440 horas. Previamente se pulieron las muestras con el fin de eliminar los primeros milímetros de su superficie que pudieran estar ya alterados por la radiación solar recibida durante el proceso de elaboración y transporte de las placas. Las medidas de color se realizaron con un colorímetro Minolta CR-200 con área de medida de $8 \mathrm{~mm}$ de diámetro y fuente de iluminación D65, incluyendo la componente especular (SCI). Se utilizaron los espacios de color CIEL*a*b* y CIEL*C*abh ab (25). El número de medidas se hizo de acuerdo con la metodología desarrollada por Sanmartín et al. (26). Los cambios de color se midieron siguiendo el procedimiento expresado en la norma EN ISO 105-A05:1997 (27), calculando la diferencia de color $\left(\Delta \mathrm{E}^{*}\right)$ según la fórmula [2]: inspected visually, indicating any peeling, breaking, cracking or rusting that might have occurred.

\section{EN 11507:2007 Exposure to fluorescent UV}

To measure the resistance of the slate tiles to the effects of UV rays, samples were exposed to ultraviolet light from a Philips HPR 125W HG UV lamp, with a maximum emission of between 300 and $400 \mathrm{~nm}$, placed at a distance of $50 \mathrm{~cm}$ above the samples in a closed chamber for 1,440 hours. All the samples had previously been polished in order to remove the first millimetres of the surface, which could have already been altered by exposure to solar radiation during the manufacture and transport of the tiles. Color measurements were made with a Minolta CR-200 spectrometer, with a measuring area $8 \mathrm{~mm}$ in diameter and a D65 illuminant, equipped with a specular component (SCI). CIEL*a*b* and CIEL*C*abh ab color spaces (25) were used. The number of measurements was made in accordance with the methodology developed by Sanmartín et al. (26). Color changes were quantified following the procedure set forth in EN ISO 105-A05:1997 (27), by calculating the energy increase $\left(\Delta E^{*}\right)$ with the formula [2]:

$$
\Delta \mathrm{E}^{*}=\left(\left(\Delta \mathrm{L}^{*}\right)^{2}+\left(\Delta \mathrm{a}^{*}\right)^{2}+\left(\Delta \mathrm{b}^{*}\right)^{2}\right)^{1 / 2}
$$

que indica el grado total del cambio de color, sin determinar la dirección ni el sentido. Las diferencias de color $\left(\Delta \mathrm{E}^{*}\right)$ se compararon con los valores de la escala de grises normalizada (28) que asocia diferencias de color al ojo humano con un número (GSc) dentro de la escala de grises. De esta manera se puede determinar si el cambio de color será apreciable o no a simple vista.

\section{Análisis digital de imagen}

Para cuantificar de manera numérica el impacto de los ensayos citados en las pizarras, se recurrió al análisis de imagen utilizando el programa de libre distribución ImageJ, versión 1.44b (29), que permite cuantificar el área total y relativa de los sulfuros de hierro y sus oxidaciones en las placas de pizarra, promediando el resultado total de las 3 placas utilizadas para cada ensayo. Los resultados del análisis de imagen se expresaron en \% de superficie ocupada por las alteraciones. Se marcaron superficies de $15 \times 15 \mathrm{~cm}$ en las placas seleccionadas aleatoriamente, tomándose imágenes antes y después de los ensayos para así poder cuantificar el crecimiento de las alteraciones.
Which indicates the overall degree of color change, without determining the direction of that change. The $\Delta E^{*}$ was compared to the values of a standard greyscale (28) that associates color differences perceived by the human eye with a value (GSC) on the greyscale, which makes it possible to determine whether or not the color change will be perceptible to the human eye.

\section{Digital Image Analysis}

Finally, to numerically quantify the impact of the listed tests in the slate samples, digital image analysis was applied using the freeware program ImageJ, version $1.44 b$ (29), which quantifies the total and relative area altered on the slate tiles' surfaces. Results for the 3 samples used in each test were averaged. The image analysis results were expressed as a percent of the area affected by the alterations. A surface of $15 \times 15 \mathrm{~cm}$ was randomly selected in every sample, taking images before and after the tests in order to quantify the growth of alterations. 


\section{RESULTADOS}

\subsection{Estudio de los carbonatos y sulfuros de hierro}

Los análisis DRX (Tabla 3), FRX y LECO (Tabla 4) muestran unas proporciones elementales y minerales típicas de las pizarras para cubiertas $(30,31)$. La semicuantificación mediante DRX muestra las proporciones de los minerales principales (cuarzo, cloritas, micas y feldespato). Las especies minerales de carbonatos y sulfuros de hierro, así como sus productos de alteración generados tras los ensayos de alterabilidad, se determinaron mediante microanálisis efectuados con el analizador EDX (Tabla 5) acoplado al SEM. Los resultados permitieron calcular las fórmulas estructurales medias de los minerales analizados. El sulfuro de hierro más común es la pirita, seguido de la pirrotina y la calcopirita. Para los carbonatos, la ankerita es el más común, y luego la calcita y la siderita.

\section{RESULTS}

\subsection{Study of carbonates and iron sulfides}

XRD analysis (Table 3), XRF and LECO (Table 4) showed that the samples contained typical elemental and mineral proportions for roofing slates $(30,31)$. Semiquantification by XRD was used to determine the proportions of the main minerals (quartz, chlorites, mica and feldspar), while EDX microanalysis was used to determine the carbonate and iron sulphide mineral phases, as well as their alteration products generated during the weatherability tests (Table 5). With these results in hand, it is possible to calculate the average structural formula for the minerals under analysis. The most common iron sulphide is pyrite, followed by pyrrhotite and chalcopyrite. For carbonates, ankerite is the most common mineral, followed by calcite and siderite.

Tabla 3 / Table 3

Resultados de la semicuantificación mineralógica de las muestras hecha mediante DRX. Results of the mineralogical semiquantification of the samples by XRD.

\begin{tabular}{|c|c|c|c|c|c|}
\hline Muestra / Sample & Cuarzo / Quartz & Clorita / Chlorite & Moscovita / Muscovite & IIlita / IIlite & Feldespato / Feldspar \\
\hline FNS & 22 & 21 & 39 & 12 & 6 \\
\hline GON & 28 & 30 & 35 & - & - \\
\hline ALS & 18 & 36 & 42 & 5 & 10 \\
\hline MOR & 19 & 23 & 41 & 7 \\
\hline
\end{tabular}

Tabla 4 / Table 4

Resultados de la determinación elemental mediante FRX y descomposición térmica catalítica LECO (3 columnas de la derecha). Results for the elemental determination by XRF and thermal catalytic decomposition LECO (3 rows to the right).

\begin{tabular}{|c|c|c|c|c|c|c|c|c|c|c|c|c|c|c|c|}
\hline $\begin{array}{c}\text { Muestra } / \\
\text { Sample }\end{array}$ & $\mathrm{SiO}_{2}$ & $\mathrm{Al}_{2} \mathrm{O}_{3}$ & $\mathrm{Fe}_{2} \mathrm{O}_{3}$ & $\mathrm{MnO}$ & $\mathrm{MgO}$ & $\mathrm{CaO}$ & $\mathrm{Na}_{2} \mathrm{O}$ & $\mathrm{K}_{2} \mathrm{O}$ & $\mathrm{TiO}_{2}$ & $\mathrm{P}_{2} \mathrm{O}_{5}$ & $\begin{array}{c}\mathrm{P} . \mathrm{F} . \text { I } \\
\text { L.O.I }\end{array}$ & Total & $\mathrm{C}$ & $\mathrm{CO}_{2}$ & $\mathbf{S}$ \\
\hline $\mathrm{FNS}$ & 55.88 & 21.46 & 7.92 & 0.10 & 2.27 & 0.27 & 0.75 & 4.84 & 0.99 & 0.21 & 4.39 & 99.07 & 0.60 & 0.13 & 0.97 \\
\hline $\mathrm{GON}$ & 59.43 & 18.60 & 7.49 & 0.06 & 2.31 & 0.74 & 1.66 & 3.57 & 1.01 & 0.19 & 4.16 & 99.21 & 0.26 & 0.70 & 0.84 \\
\hline $\mathrm{ALS}$ & 52.28 & 23.89 & 9.42 & 0.08 & 2.29 & 0.28 & 1.17 & 3.48 & 1.01 & 0.14 & 5.25 & 99.29 & 0.41 & 0.44 & 1.21 \\
\hline $\mathrm{MOR}$ & 52.94 & 24.19 & 8.64 & 0.06 & 2.08 & 0.27 & 1.21 & 3.48 & 1.06 & 0.14 & 5.10 & 99.18 & 0.64 & 0.04 & 1.54 \\
\hline
\end{tabular}

Tabla 5 / Table 5

Análisis EDX (\%) de los minerales alterables. $\mathrm{N}=$ número de muestras, Aw = \% peso atómico, $\mathrm{s}=$ desviación estándar de las medidas. Fórmulas esquetiométricas calculadas mediante las proporciones elementales halladas con el análisis EDX de las muestras. EDX analyses (\%) of the weatherable minerals. $N=$ number of samples, $A w=\%$ atomic weight, $s=$ standard deviation. Stoichiometric formula calculated from the elemental proportions from the EDX analyses.

\begin{tabular}{|c|c|c|c|c|c|c|c|c|c|c|c|c|}
\hline & \multicolumn{2}{|c|}{ Pirita / Pyrite } & \multicolumn{2}{|c|}{$\begin{array}{l}\text { Pirrotina I } \\
\text { Pyrrhotite }\end{array}$} & \multicolumn{2}{|c|}{$\begin{array}{l}\text { Calcopirita I } \\
\text { Chalcopyrite }\end{array}$} & \multicolumn{2}{|c|}{ Calcita / Calcite } & \multicolumn{2}{|c|}{ Ankerita / Ankerite } & \multicolumn{2}{|c|}{ Siderita / Siderite } \\
\hline $\mathrm{N}$ & \multicolumn{2}{|c|}{24} & \multicolumn{2}{|c|}{15} & \multicolumn{2}{|c|}{4} & \multicolumn{2}{|c|}{12} & \multicolumn{2}{|c|}{22} & \multicolumn{2}{|c|}{8} \\
\hline Muestra / Sample & \multicolumn{2}{|c|}{ FNS, GON, ALS, MOR } & \multicolumn{2}{|c|}{ FNS, ALS, MOR } & \multicolumn{2}{|c|}{ MOR } & \multicolumn{2}{|c|}{ FNS, MOR } & \multicolumn{2}{|c|}{ FNS, GON, ALS, MOR } & \multicolumn{2}{|c|}{ FNS, ALS } \\
\hline Elemento / Element & Aw & $\mathrm{s}$ & Aw & $\mathrm{s}$ & Aw & $\mathrm{s}$ & Aw & $\mathrm{s}$ & Aw & $\mathrm{s}$ & $\mathrm{Aw}$ & $\mathrm{s}$ \\
\hline $\mathrm{Cu}$ & & & & & 34.68 & 0.32 & & & & & & \\
\hline $\mathrm{Fe}$ & 44.72 & 0.17 & 61.98 & 0.50 & 30.46 & 0.14 & 0.54 & 0.05 & 11.39 & 0.15 & 46.53 & 0.16 \\
\hline $\mathrm{Mg}$ & & & & & & & & & 5.70 & 0.19 & 0.21 & 0.02 \\
\hline As & 0.37 & 0.04 & & & & & & & & & & \\
\hline $\mathrm{Ca}$ & & & & & & & 42.85 & 0.21 & 20.84 & 0.53 & 0.34 & 0.01 \\
\hline C & & & & & & & 12.35 & 0.26 & 12.37 & 0.27 & 10.82 & 0.41 \\
\hline$S$ & 52.66 & 0.21 & 37.07 & 0.09 & 34.86 & 0.27 & & & & & & \\
\hline 0 & & & & & & & 44.26 & 0.14 & 49.42 & 0.61 & 41.49 & 0.24 \\
\hline $\begin{array}{c}\text { Fórmulas calculadas / } \\
\text { Calculated formula }\end{array}$ & \multicolumn{2}{|c|}{$\left(\mathrm{Fe}_{0.98}, \mathrm{As}_{0.01}\right) \mathrm{S}_{2}$} & \multicolumn{2}{|c|}{$\mathrm{Fe}_{0.96} \mathrm{~S}$} & \multicolumn{2}{|c|}{$\mathrm{Cu}_{0.99} \mathrm{Fe}_{1.01} \mathrm{~S}_{2}$} & \multicolumn{2}{|c|}{$\left(\mathrm{Ca}_{0.99}, \mathrm{Fe}_{0.01}\right) \mathrm{CO}_{3}$} & \multicolumn{2}{|c|}{$\mathrm{Ca}_{0.54}\left(\mathrm{Fe}_{0.21}, \mathrm{Mg}_{0.01}\right) \mathrm{CO}_{3}$} & \multicolumn{2}{|c|}{$\left(\mathrm{Fe}_{0.98}, \mathrm{Ca}_{0.01}, \mathrm{Mg}_{0.01}\right) \mathrm{CO}_{3}$} \\
\hline
\end{tabular}


Los análisis POL y SEM (Tabla 6) permiten diferenciar las siguientes tipologías de componentes alterables:

- Cubos de pirita de tamaño micrométrico, que se suelen encontrar formando framboides, y cubos de pirita de tamaño milimétrico, que suelen aparecer como cubos aislados (Figuras $5 a$ y $5 b$ ).

- Sulfuros de hierro, predominando la pirrotina, que suelen encontrarse como sustituciones de conchas fósiles (Figura 5c), y nódulos y vetas micrométricos.

- Carbonatos formando nódulos centimétricos que aparecen sobre los planos de exfoliación, en la superficie de las placas (Figura $5 d$ ).

- Blastos de carbonatos de tamaño micrométrico que se presentan rellenado huecos en la matriz de la pizarra con textura mosaico, o bien clastos de caliza de mayor tamaño (Figura 5e).

- La materia orgánica se encuentra repartida homogéneamente en cuanto a tamaño y abundancia en todas las muestras (Figura $5 f$ ).
POL and SEM analyses (Table 6) make it possible to discern the following typologies of alterable components:

- Cubes of micrometer-sized pyrite, which are often found in the form of framboids, and cubes of millimeter-sized pyrite, which often occur as isolated blocks (Figures 5a and 5b).

- Iron sulfides, mainly pyrrhotite, usually found as replacements of fossil shells (Figure $5 c$ ), nodules and micrometer nodules.

- Carbonates forming centimetric nodules, which show up in the slaty cleavage planes, and are visible on the surface of the slate tiles (Figure 5d).

- Blasts of micrometer-sized carbonates that fill pores in the matrix with a mosaic texture, or limestone clasts contained within the slate matrix (Figure 5e).

- Organic matter is distributed uniformly in size and abundance throughout all the samples (Figure 5f).

Tabla 6 / Table 6

Morfología y tamaño de los componentes alterables de las pizarras determinados mediante POL. Entre paréntesis, la estimación visual porcentual de los minerales.

Size and morphology ofsaltes weatherable components determined by POL. In brackets visual percental estimation of minerals.

\begin{tabular}{|c|c|c|c|}
\hline Muestra / Sample & Sulfuros de hierro / Iron sulfides & Carbonatos / Carbonates & Materia orgánica / Organic matter \\
\hline FNS & $\begin{array}{l}\text { Framboides } 200-1000 \mu \mathrm{m}(2 \%) / \\
\text { Framboids } 200-1000 \mu \mathrm{m}(2 \%)\end{array}$ & $\begin{array}{l}\text { Rellenos mosaico poros } 100-200 \mu \mathrm{m}(1 \%) / \\
\text { Pore mosaic filling } 100-200 \mu \mathrm{m}(1 \%)\end{array}$ & $\begin{array}{l}\text { Fragmentos } 20-80 \mu \mathrm{m}(<1 \%) / \\
\text { Fragments } 20-80 \mu \mathrm{m}(<1 \%)\end{array}$ \\
\hline GON & $\begin{array}{l}\text { Cubos } 100-250 \mu \mathrm{m}(1 \%) / \\
\text { Cubes } 100-250 \mu \mathrm{m}(1 \%)\end{array}$ & No observado / Not observed & $\begin{array}{l}\text { Fragmentos } 10-40 \mu \mathrm{m}(<1 \%) / \\
\text { Fragments } 10-40 \mu \mathrm{m}(<1 \%)\end{array}$ \\
\hline ALS & $\begin{array}{l}\text { Framboides } 500-2000 \mu \mathrm{m}(4 \%) / \\
\text { Framboids } 500-2000 \mu \mathrm{m}(4 \%)\end{array}$ & $\begin{array}{l}\text { Relleno mosaico poros } 100-200 \mu \mathrm{m}(<1 \%) / \\
\quad \text { Pore mosaic filling } 100-200 \mu \mathrm{m}(1 \%)\end{array}$ & $\begin{array}{l}\text { Fragmentos } 10-40 \mu \mathrm{m}(<1 \%) / \\
\text { Fragments } 10-40 \mu \mathrm{m}(<1 \%)\end{array}$ \\
\hline MOR & $\begin{array}{c}\text { Cubos } 150-300 \mu \mathrm{m} \text { y framboides } \\
150-500 \mu \mathrm{m}(4 \%) / \text { Cubes } 150-300 \mu \mathrm{m}, \\
\text { framboids } 150-500 \mu \mathrm{m}(4 \%)\end{array}$ & $\begin{array}{l}\text { Blastos } 200-500 \mu \mathrm{m}(2 \%) / \\
\text { Blasts } 200-500 \mu \mathrm{m}(2 \%)\end{array}$ & $\begin{array}{l}\text { Fragmentos } 10-40 \mu \mathrm{m}(<1 \%) / \\
\text { Fragments } 10-40 \mu \mathrm{m}(<1 \%)\end{array}$ \\
\hline
\end{tabular}

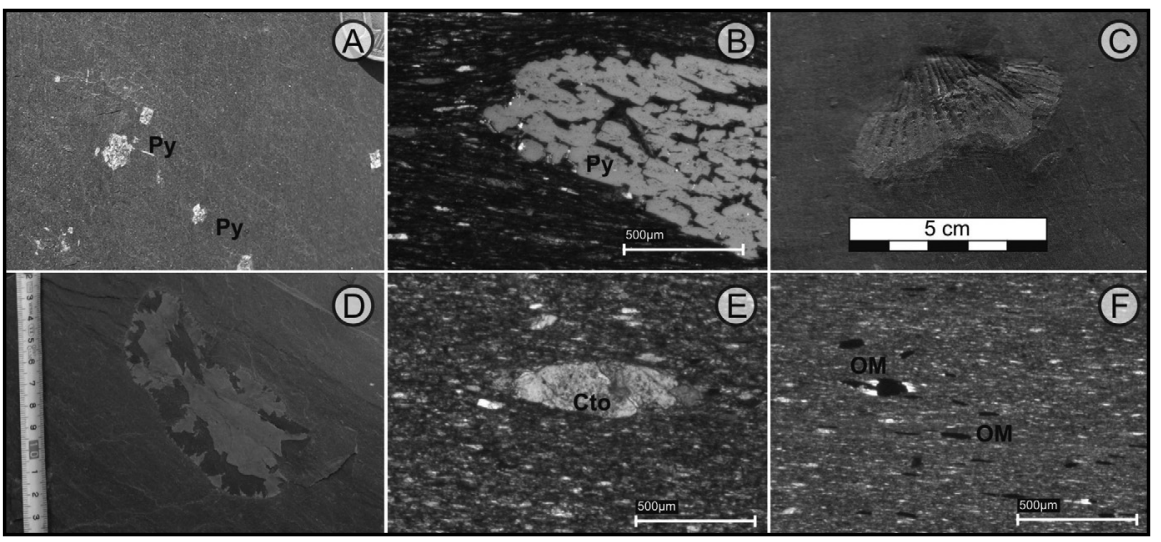

Figura 5. Imágenes de microscopio óptico y visu de los componentes alterables: $5 \mathrm{~A}$ Cubos de pirita (Py), muestra MOR. 5B Framboide de pirita (Py) compuesto por cubos micrométricos, microscopio óptico de luz reflejada, analizadores cruzados, muestra ALS. 5C Braquiópodo (Rhynchonella sp., com. pers. Ma. L. Martínez-Chacón) pirrotinizado, muestra MOR. 5D Nódulo de carbonato (ankerita), muestra FNS. 5E Cristal de carbonato (Cto), microscopio óptico de luz transmitida, analizadores cruzados, muestra MOR. 5F Materia orgánica (OM) opaca dispersa por toda la lámina, microscopio óptico de luz transmitida, analizadores cruzados, muestra FNS.

Figure 5. Optical microscope and hand specimen images of the weatherable components: 5A Pyrite (Py) cubes, MOR sample. 5B

Pyrite framboid (Py), formed by micrometric cubes, optical microscope of reflected light, cross analyzers, ALS sample. 5C brachiopod (Rhynchonella sp., per. com.. Ma. L. Martínez-Chacón, UNIOVI). 5D Carbonate nodule (ankerite), FNS sample. 5E Carbonate cristal (Cto), optical microscope of transmitted light, cross analyzers, MOR sample. 5F Opaque organic matter (OM) scattered all over the sample, optical microscope of transmitted light, cross analyzers, FNS sample. 


\subsection{Estudio de las alteraciones}

El estudio de las patologías producidas por los diferentes ensayos muestra la formación de óxidos de hierro sobre la superficie de los sulfuros de hierro (Figuras 6a, 6b, 6c y 6d) durante el ensayo de ciclo térmico y la niebla salina, y cristales aciculares milimétricos diseminados por la superficie de la pizarra (Figuras 6e y 6f) durante el ensayo de exposición al $\mathrm{SO}_{2}$. En este último ensayo, los sulfuros de hierro también se alteran, debido a la elevada acidez del medio, aunque estas alteraciones no son como las ocasionadas durante el ciclo térmico, ya que no hay difusión de la oxidación a lo largo de la placa de pizarra y la alteración se reduce a la propia superficie del sulfuro de hierro. Los estudios EDX de estas alteraciones (Tabla 7) revelan que, para los sulfuros de hierro, la alteración es siempre a óxidos de hierro (goethita), mientras

\subsection{Alterations}

The study of the pathologies caused by the different tests shows the formation of iron oxides on the surface of the iron sulfides (Figures 6a, 6b, 6c and 6d) during the thermal cycle and salt spray tests, and the formation of millimetric gypsum crystals scattered all across the surface of the slate tiles (Figures $6 r$ and $6 f$ ) during the exposure to $\mathrm{SO}_{2}$ test. In this last test, the iron sulfides are also weathered due to the high acidity of the medium, although the morphology of these alterations is different than in the thermal cycle, since there is no diffusion of oxidation along the slate surface. Rather, the alteration is limited to the surface of the iron sulfide. EDX analysis (Table 7) showed that, while iron sulphides always turn into iron oxides when altered (goethite), the carbonates undergo much more complex alterations.

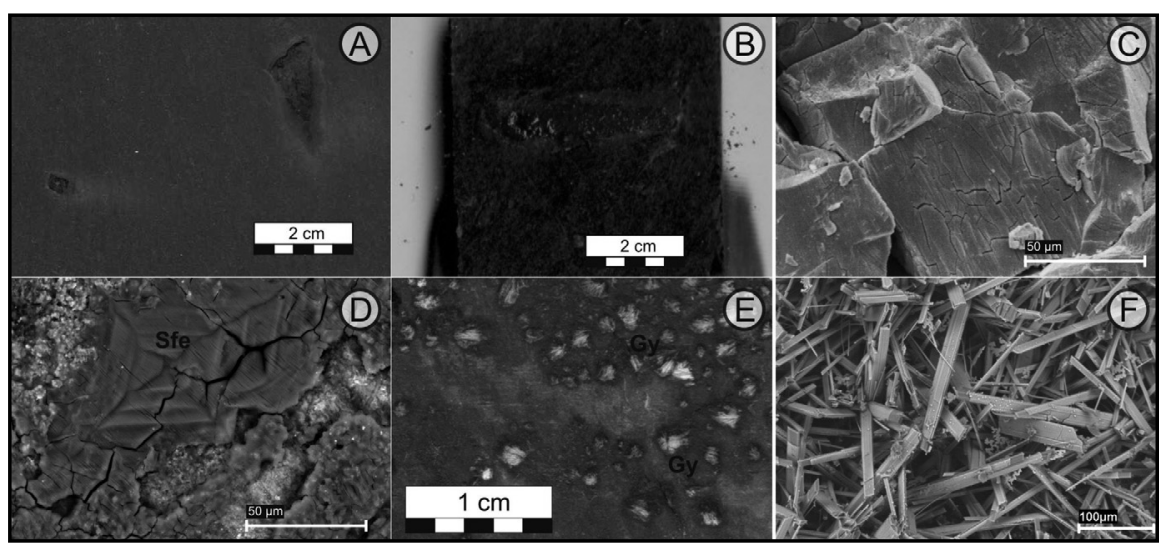

Figura 6. Imágenes de alteraciones producidas durante los ensayos: $6 \mathrm{~A}$ Sulfuros de hierro alterados después del ensayo de choque térmico, muestra MOR. 6B Sulfuro de hierro alterado después del ensayo de exposición al $\mathrm{SO}_{2}$, muestra MOR. 6C Imagen SEM de la superficie de alteración de un sulfuro de hierro después del ensayo de exposición al $\mathrm{SO}_{2}$, muestra MOR. 6D Imagen SEM de la superficie de alteración de un sulfuro de hierro (SFe) después del ensayo de choque térmico, muestra MOR. 6E Imagen SEM de cristales de yeso (Gy) formados durante el ensayo de exposición al $\mathrm{SO}_{2}$, muestra GON. $6 \mathrm{~F}$ Imagen SEM de los cristales de yeso formados durante el ensayo de exposición al $\mathrm{SO}_{2}$. Figure 6. Images if the alterations formed during the tests: $6 \mathrm{~A}$ Weathered iron sulfides after the thermal cycle test, MOR sample. 6B Weathered iron sulfide after the exposure to $\mathrm{SO}_{2}$ test, MOR sample. $6 \mathrm{C} \mathrm{SEM}$ image of the alterations of an iron sulfide after the exposure to $\mathrm{SO}_{2}$ test, $M O R$ sample. 6D SEM image of the alterations of an iron sulfide (SFe) after the thermal cycles, MOR sample. 6E SEM image of gypsum crystals (Gy)

formed during the exposure to $\mathrm{SO}_{2}$ test, GON sample. $6 \mathrm{~F} \mathrm{SEM} \mathrm{image} \mathrm{of} \mathrm{gypsum} \mathrm{crystals} \mathrm{formed} \mathrm{during} \mathrm{the} \mathrm{exposure} \mathrm{to} \mathrm{SO}_{2}$ test.

Tabla 7 / Table 7

Análisis EDX (\%) de las fases minerales resultantes después de la alteración producida durante los ensayos de ciclo térmico y exposición al $\mathrm{SO}_{2} . \mathrm{N}=$ número de muestras, $\mathrm{Aw}=\%$ peso atómico, $\sigma=$ desviación estándar de las medidas. Fórmulas esquetiométricas calculadas mediante las proporciones elementales halladas con el análisis EDX de las muestras.

EDX analyses (\%) of mineral phases resulting from weathering produced alter termal cycles and exposure to $\mathrm{SO}_{2} . \mathrm{N}=$ numer of samples, $A w=\%$ atomic weight, $\sigma=$ standard deviation. Stoichiometric formula calculated from the elemental proportions from the EDX analyses.

\begin{tabular}{|c|c|c|c|c|c|c|c|c|}
\hline & \multicolumn{2}{|c|}{ Goetita / Goethite } & \multicolumn{2}{|c|}{ Epsomita / Epsomite } & \multicolumn{2}{|c|}{ Melanterita / Melanterite } & \multicolumn{2}{|c|}{ Yeso / Gypsum } \\
\hline $\mathrm{N}$ & \multicolumn{2}{|c|}{20} & \multicolumn{2}{|c|}{8} & \multicolumn{2}{|c|}{15} & \multicolumn{2}{|c|}{21} \\
\hline Muestra / Sample & \multicolumn{2}{|c|}{ FNS, GON, ALS, MOR } & \multicolumn{2}{|c|}{ FNS, ALS } & \multicolumn{2}{|c|}{ FNS, GON, ALS, MOR } & \multicolumn{2}{|c|}{ FNS, GON, ALS, MOR } \\
\hline Elemento / Element & Aw & $\sigma$ & $A w$ & $\sigma$ & Aw & $\sigma$ & Aw & $\sigma$ \\
\hline $\mathrm{Fe}$ & 66.58 & 0.41 & 5.04 & 0.06 & 22.42 & 0.38 & 1.34 & 0.13 \\
\hline $\mathrm{Mg}$ & & & 9.62 & 0.62 & & & & \\
\hline $\mathrm{Ca}$ & & & 12.98 & 0.09 & 1.46 & 0.21 & 25.59 & 0.25 \\
\hline$S$ & 2.66 & 0.17 & 11.88 & 0.20 & 11.93 & 0.35 & 18.96 & 0.12 \\
\hline 0 & 30.76 & 0.54 & 60.48 & 0.45 & 64.19 & 0.60 & 54.11 & 0.31 \\
\hline $\begin{array}{l}\text { Fórmulas calculadas / } \\
\text { Calculated formula }\end{array}$ & \multicolumn{2}{|c|}{$\mathrm{Fe}_{2.31} \mathrm{~S}_{0.09} \mathrm{O} \cdot(\mathrm{OH})$} & \multicolumn{2}{|c|}{$\left(\mathrm{Mg}_{0.16}, \mathrm{Fe}_{0.08}, \mathrm{Ca}_{0.21}\right) \mathrm{S}_{0.19} \mathrm{O} \cdot 7 \mathrm{H}_{2} \mathrm{O}$} & \multicolumn{2}{|c|}{$\left(\mathrm{Fe}_{0.35}, \mathrm{Ca}_{0.02}\right) \mathrm{SO}_{0.17} \cdot 7 \mathrm{H}_{2} \mathrm{O}$} & \multicolumn{2}{|c|}{$\left(\mathrm{Ca}_{0.46}, \mathrm{Fe}_{0.24}\right) \mathrm{S}_{0.34} \mathrm{O} \cdot 2 \mathrm{H}_{2} \mathrm{O}$} \\
\hline
\end{tabular}


que las alteraciones producidas en los carbonatos son más complejas. El producto de alteración más común es el yeso, seguido de melanterita y epsomita. Estas alteraciones son ricas en $\mathrm{Fe}$, al igual que los carbonatos originales.

Los incrementos absolutos en el área alterada (Tabla 8) por el ensayo de ciclo térmico (Figura 7) son del orden del $200 \%$, siendo el máximo $(250 \%)$ el producido en la muestra MOR y el mínimo $(162,1 \%)$ en ALS. Las alteraciones producidas en los sulfuros de hierro son de colores intensos rojo-amarillentos. Las especies de sulfuros de hierro presentes se corresponden con pirita y pirrotina
The most common product of alteration is gypsum, followed by melanterite and epsomite. These alterations are rich in Fe, just like the original carbonates.

Absolute increases in the altered area (Table 8) during the thermal cycle test (Figure 7) are on the order of $200 \%$, the maximum of which (250\%) was formed in the MOR sample, and the minimum (162.1\%) in ALS. The alterations produced are bright red/yellow in color. The species of sulphides correspond to pyrite and pyrrhotite for the samples with larger weathered areas (FNS and

Tabla 8 / Table 8

Resultados del análisis de imagen efectuado con el programa ImageJ para los ensayos de ciclo térmico, exposición al $\mathrm{SO}_{2}$ y niebla salina. Results of image analyses carried out with software ImageJ for the termal cycle, exposure to $\mathrm{SO}_{2}$ and saline mist tests.

\begin{tabular}{|c|c|c|c|}
\hline & Previo (\% área) / Previous (\% area) & Posterior ( $\%$ área) / Later ( $\%$ area) & Incremento (\%) / Increase (\%) \\
\hline \multicolumn{4}{|c|}{ FNS } \\
\hline Ciclo térmico / Thermal cycles & 4.5 & 8.6 & 191.1 \\
\hline Exposición $\mathrm{SO}_{2} /$ Exposure $\mathrm{SO}_{2}$ & 3.8 & 6.6 & 173.7 \\
\hline Niebla salina / Saline mist & 4.6 & 5.6 & 121.7 \\
\hline \multicolumn{4}{|c|}{ GON } \\
\hline Ciclo térmico / Thermal cycles & 2.6 & 5.2 & 200.0 \\
\hline Exposición $\mathrm{SO}_{2} /$ Exposure $\mathrm{SO}_{2}$ & 6.5 & 7.1 & 109.2 \\
\hline Niebla salina / Saline mist & 3.5 & 5.7 & 162.8 \\
\hline \multicolumn{4}{|c|}{ ALS } \\
\hline Ciclo térmico / Thermal cycles & 12.4 & 20.1 & 162.1 \\
\hline Exposición $\mathrm{SO}_{2} /$ Exposure $\mathrm{SO}_{2}$ & 10.4 & 16.3 & 156.7 \\
\hline Niebla salina / Saline mist & 11.2 & 16.6 & 148.2 \\
\hline \multicolumn{4}{|c|}{ MOR } \\
\hline Ciclo térmico / Thermal cycles & 4.2 & 10.5 & 250.0 \\
\hline Exposición $\mathrm{SO}_{2} /$ Exposure $\mathrm{SO}_{2}$ & 5.0 & 6.2 & 124.0 \\
\hline Niebla salina / Saline mist & 6.5 & 10.2 & 156.9 \\
\hline
\end{tabular}

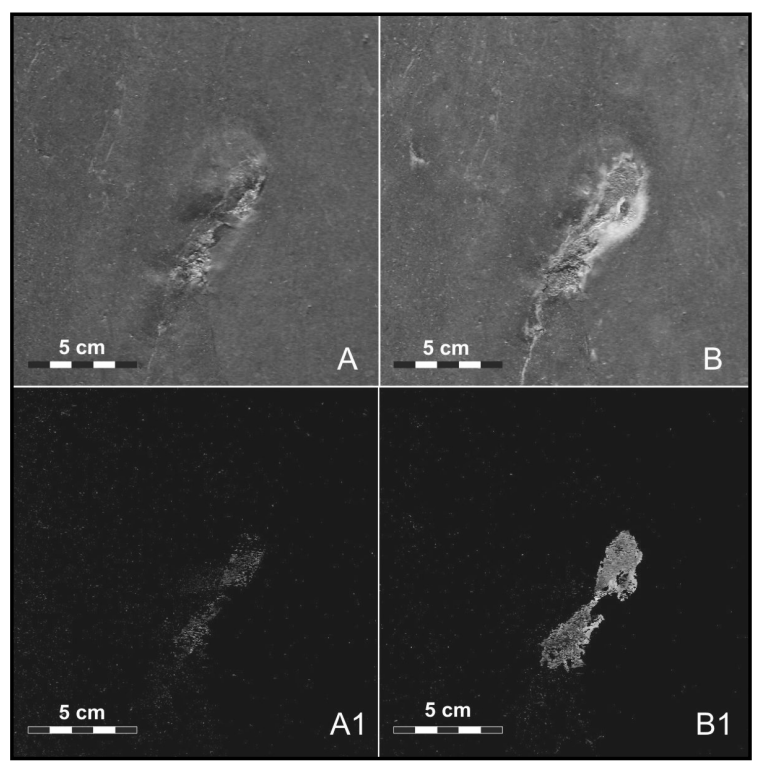

Figura 7. Análisis de imagen correspondiente a las alteraciones producidas durante el ensayo de ciclo térmico. La figura 7A corresponde a un sulfuro de hierro antes del ensayo, siendo 7A1 su correspondiente cuantificación por análisis de imagen. La figura

7B corresponde al mismo sulfuro de hierro una vez alterado, siendo 7B1 la cuantificación del área ocupada por la alteración.

Figure 7. Image analysis of the alterations produced during the termal cycle test. Figure $7 A$ corresponds to an iron sulfide before the test, being 7A1the image quantification. Figure $7 B$ corresponds to the same iron sulfide after the test, being 7B1 the quantification of the alteration area. 
para las muestras con mayor área alterada (FNS y MOR), y solo pirita para las muestras con menor área alterada (GON y ALS). En el ensayo de exposición al $\mathrm{SO}_{2}$ (Figura 8), el valor máximo se obtuvo para la muestra FNS $(173,7 \%)$ y el mínimo en la muestra GON (109,2\%). Estas alteraciones son amarillo-blanquecinas y difusas. La muestra FNS posee también el mayor contenido en calcita, mientras que el resto de muestras presentan calcita y ankerita. Para el envejecimiento mediante niebla salina, el incremento máximo corresponde a GON $(162,8 \%)$ y el mínimo corresponde a FNS $(121,7 \%)$. La intensidad de las alteraciones no es tan elevada como en el caso del ciclo térmico o la exposición al $\mathrm{SO}_{2}$, produciéndose manchas difusas de color anaranjado en torno a los sulfuros de hierro y un ligero blanqueamiento general de la placa (Figura 9) debido a la deposición de sales en su superficie. En este caso, no hay una relación clara entre la mineralogía de los sulfuros de hierro y el área alterada por el envejecimiento mediante niebla salina. Sin embargo, si parece haber una cierta relación entre el tamaño de los sulfuros de hierro y el área alterada.

La exposición a radiación UV pone de manifiesto en todas las pizarras un incremento en la luminosidad $L^{*}$ después de 1.440 horas, junto con una disminución en los valores de C* (Figura 10, Tabla 9). La pizarra que ha experimentado una mayor variación en $\mathrm{L}^{*}$ es FNS, con un incremento de 2,21 , mientras que la menor variación corresponde

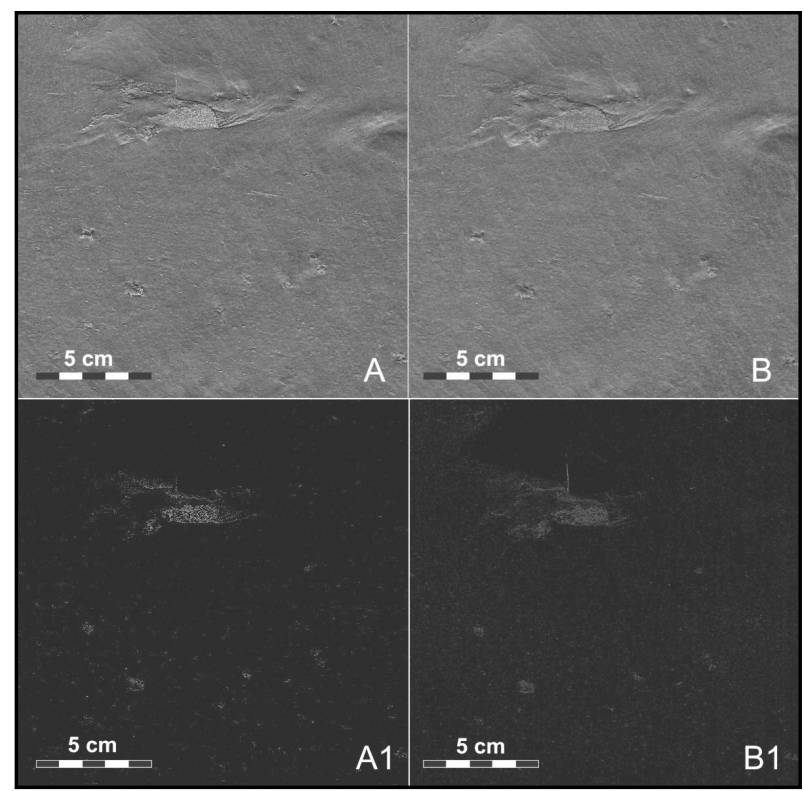

Figura 8. Análisis de imagen correspondiente a las alteraciones producidas durante el ensayo de exposición al $\mathrm{SO}_{2}$. La figura $8 \mathrm{~A}$ corresponde a un sulfuro de hierro antes del ensayo, siendo $8 \mathrm{~A} 1 \mathrm{su}$ correspondiente cuantificación por análisis de imagen. La figura 8B corresponde al mismo sulfuro de hierro una vez alterado, siendo

8B1 la cuantificación del área ocupada por la alteración.

Figure 8. Image analysis of the alterations produced during the exposure to $\mathrm{SO}_{2}$ test. Figure $8 \mathrm{~A}$ corresponds to an iron sulfide before the test, being $8 A 1$ the image quantification. Figure $8 B$ corresponds to the same iron sulfide after the test, being $8 B 1$ the quantification of the alteration area.
MOR), and only pyrite for the samples with smaller weathered areas (GON and ALS). In the exposure to $\mathrm{SO}_{2}$ test (Figure 8), the value for the maximum altered area was obtained for the FNS sample (173.7\%), while the minimum value was obtained for the GON sample (109.2\%). These alterations are yellow/white and faint. For the aging by salt mist test, GON had the maximum altered area (162.8\%), while FNS had the minimum $(121.7 \%)$. Here the alterations were less intense than in the thermal cycle or exposure to $\mathrm{SO}_{2}$ tests, producing faint orange spots around the iron sulphides, and a general whitening of the slate surface (Figure 9) due to salt deposition. Although there is not a clear relationship between the mineralogy of the iron sulphides and the area altered by the saline mist, there is indeed a clear relationship between the size of the iron sulphides and the altered area.

After 1440 hours of exposure to UV radiation, all of the slates showed an increase in the luminosity parameter $L^{*}$, together with a decrease in the values of $C^{*}$ (Figure 10, Table 9). The FNS slate underwent a major change in $L^{*}$, with an increase of 2.21, while GON displayed the lowest variation, with an increase of just 0.17 . FNS also

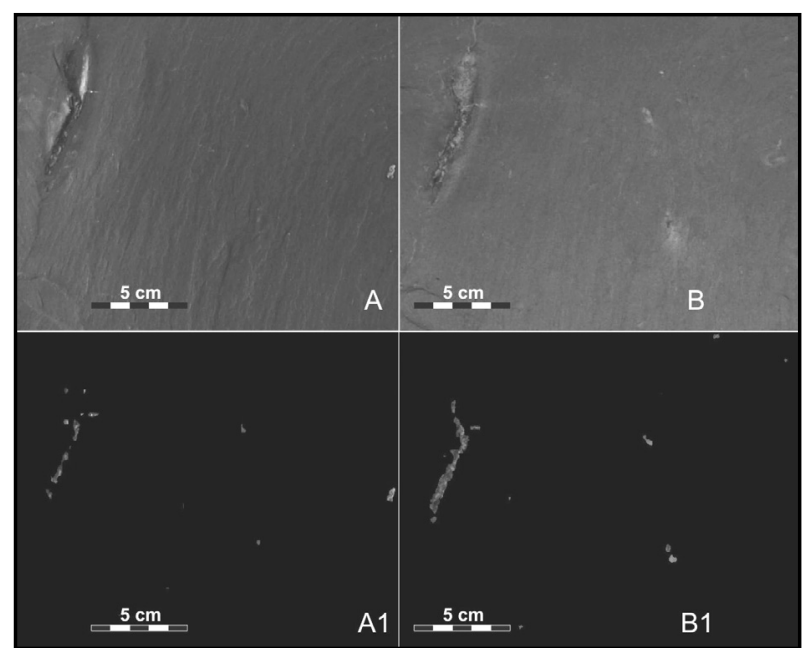

Figura 9. Análisis de imagen correspondiente a las alteraciones producidas durante el ensayo de exposición a niebla salina. La figura 9A corresponde a un sulfuro de hierro antes del ensayo, siendo 9A1 su correspondiente cuantificación por análisis de imagen. La figura $9 \mathrm{~B}$ corresponde al mismo sulfuro de hierro una vez alterado, siendo 9B1 la cuantificación del área ocupada por la alteración. Figure 9. Image analysis of the alterations produced during the saline mist test. Figure $9 A$ corresponds to an iron sulfide before the tests, being $9 A 1$ the image quantification. Figure $9 B$ corresponds to the same iron sulfide after the test, being 9B1 the quantification of the alteration area. 
a GON, con un incremento de 0,17. La mayor variación en C* también es para FNS, con -0,33, así como la menor variación, $-0,10$, que corresponde a su vez a GON. En lo que se refiere a las diferencias en la escala de grises GSc, FNS muestra el mayor cambio $(2,26)$, que se corresponde a un ligero cambio apreciable por el ojo humano, mientras que las otras tres pizarras muestran cambios apreciables (GON) o en el límite de apreciación (ALS y MOR).

\section{CONCLUSIONES}

- Las técnicas de caracterización más útiles para la determinación de los minerales alterables de la pizarra son el análisis petrográfico mediante microscopio óptico y la descomposición térmica catalítica, ambas recogidas en la Norma EN 12326:2005. Estas técnicas se complementan con el análisis EDX, que es capaz de discernir entre las distintas especies de minerales alterables. El análisis mediante DRX no proporciona información útil sobre los minerales alterables, ya que estos no se encuentran en proporciones suficientemente altas como para ser detectados mediante este método. Las mayores alteraciones de oxidación para el ciclo térmico se produjeron en las pizarras con mayor contenido elemental, medido mediante FRX, en S y pirrotina (MOR), mientras que para la exposición al $\mathrm{SO}_{2}$ las mayores alteraciones se produjeron en pizarras con altos contenidos elementales en $\mathrm{Ca}$ (GON).

- Los sulfuros de hierro dominantes en las pizarras estudiadas son la pirita y la pirrotina, los cuales se alteran a goethita. La pirrotina presenta una mayor underwent the greatest change in $C^{*}$, with a decrease of -0.33 , while GON again displayed the lowest variation, a decrease of -0.10. As for differences in the greyscale GSc, FNS showed the greatest change (2.26), which corresponds to a slight shift that is visible to the human eye, while the other three slates showed either no significant changes (GON), or changes that were just barely visible (ALS and MOR).

\section{CONCLUSIONS}

- The most useful characterization techniques for determining the alterable minerals in roofing slates are petrographical analysis by optical microscopy and thermal catalytic decomposition, both described in standard EN 12326:2005. EDX analyses constitute a perfect complement to these techniques, as they make it possible to distinguish between the different species of weatherable minerals. XRD analysis does not give useful information about alterable minerals, since they are not found in high enough proportions to be detected by this analytical method. The greatest alterations due to oxidation in the thermal cycle took place in samples with a higher content of $S$ and pyrrhotite (MOR), measured by XRD, while the greatest alterations due to $\mathrm{SO}_{2}$ exposure took place in slates with an elemental content high in $\mathrm{Ca}$ (GON).

- The predominant iron sulphides in the slates studied are pyrite and pyrrhotite, which when altered turns into goethite. Pyrrhotite displayed a higher alteration

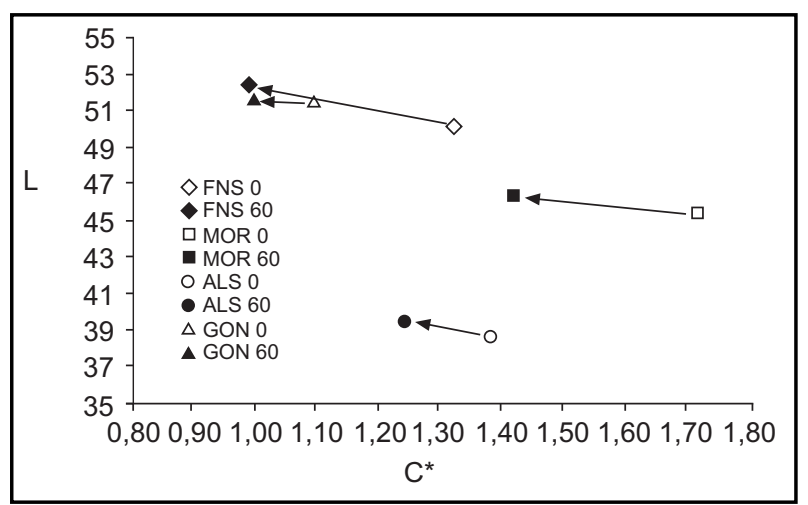

Figura 10. Diagrama $L^{*} C^{*}$ de las medidas de color efectuadas en las pizarras a 0 horas y 1.440 horas. Las flechas indican la cariación para cada muestra.

Figure 10. $L^{*} C^{*}$ diagram of the color measures in the saltes at 0 and 1440 hours. Arrows indicates the variation for each sample.

Tabla 9 / Table 9

Medidas cromáticas realizadas en las pizarras a las 0 horas y a las 1.440 horas de exposición a radiación UV. Chromatic measures from slates at 0 hours and alter 1440 hours of exposure to UV radiation.

\begin{tabular}{|c|c|c|c|c|c|c|c|c|c|c|}
\hline & $\mathbf{L}^{*}{ }_{0}$ & $\mathbf{a}^{*}{ }_{0}$ & $\mathbf{b}^{*}{ }_{0}$ & $\mathbf{C}^{*}{ }_{0}$ & $\mathbf{L}^{*}{ }_{1440}$ & $\mathbf{a}^{*}{ }_{1440}$ & $\mathbf{b}^{*}{ }_{1440}$ & $\mathbf{C}^{*}{ }_{1440}$ & $\Delta \mathbf{E}^{*}$ & Cambios ojo / Changes to naked eye \\
\hline FNS & 50.22 & -0.83 & -1.03 & 1.32 & 52.43 & -0.78 & -0.57 & 0.99 & 2.26 & Ligero / Slight \\
\hline GON & 51.28 & -0.74 & -0.81 & 1.10 & 51.45 & -0.78 & -0.61 & 1.00 & 0.27 & No visible / not appreciable \\
\hline ALS & 38.68 & -0.33 & -1.34 & 1.38 & 39.39 & -0.36 & -1.19 & 1.25 & 0.73 & Límite / Limit \\
\hline MOR & 45.30 & -0.36 & -1.67 & 1.71 & 45.90 & -0.52 & -1.30 & 1.40 & 0.72 & Límite / Limit \\
\hline
\end{tabular}


tasa de alteración que la pirita, siendo más perjudicial desde el punto de vista de calidad del producto comercial. Los carbonatos están representados por ankerita, calcita y siderita, alterándose principalmente a yeso rico en $\mathrm{Fe}^{3+}$, melanterita y epsomita. El $\mathrm{Fe}^{3+}$ está presente en todas las alteraciones de los carbonatos, lo que explica el tono rojo-anaranjado que tienen estas alteraciones.

- Cada uno de los ensayos de alterabilidad incluidos en la Norma EN 12326 evidencia un tipo de alteración diferente. El ensayo de ciclo térmico incide sobre la oxidabilidad de los sulfuros de hierro presentes mediante sucesivos ciclos de deshidratación-hidratación de los mismos, favoreciéndose el paso de $\mathrm{Fe}^{2+}$ a $\mathrm{Fe}^{3+}$. La respuesta frente a este ensayo depende en gran medida de la mineralogía de estos sulfuros de hierro, siendo más alterable la pirrotina que la pirita.

- La exposición al $\mathrm{SO}_{2}$ ataca fundamentalmente a los carbonatos, que pasan a forman yeso, aumentando de tamaño y afectando a la cohesión de la pizarra, favoreciendo los procesos de exfoliación, fragmentación, etc. Los sulfuros de hierro también se ven afectados por este ensayo, si bien la tipología de las alteraciones es distinta a la generada durante el ensayo de ciclo térmico.

- Otros ensayos normativos pueden ser empleados junto con los de EN 12326:2005. El envejecimiento mediante niebla salina (EN 14147:2004) afecta a los sulfuros de hierro, mediante la creación de un medio ambiente salino con un alto electrolito de fondo que favorece la reacción $\mathrm{Fe}^{2+}$ a Fe ${ }^{3+}$. Las alteraciones producidas en este ensayo generalmente ocupan una mayor superficie que las producidas durante el ciclo térmico, pero por el contrario presentan menor intensidad. La exposición a los rayos UV (EN 11507:2007) pone de manifiesto los cambios potenciales de color en las pizarras.

- La evaluación de la alterabilidad potencial de una pizarra para cubiertas se puede llevar a cabo empleando estos ensayos, los cuales afectan exclusivamente a los minerales alterables que pudiera haber en la pizarra. Asimismo, la cuantificación de las alteraciones producidas en estos ensayos se puede llevar a cabo mediante análisis de imagen, que es una técnica más objetiva que la estimación visual que se contempla actualmente en las normas.

\section{AGRADECIMIENTOS}

El presente trabajo se ha desarrollado en el marco del proyecto PERDURABLE: Durabilidad de materiales de piedra natural. Análisis y prevención de patologías. MICINN-09CIT-380000-2009-25, financiado por el Ministerio de Ciencia e Innovación. Gracias también a la Fundación Centro Tecnológico de la Pizarra, Sobradelo de Valdeorras, y a su directora Cristina Álvarez por su ayuda en la realización de los ensayos y a Nicholas Callaway por su revisión del trabajo. rate than pyrite, which makes it more harmful in terms of commercial quality. Carbonates are represented by ankerite, calcite and siderite, which when altered mainly turn into gypsum rich in $\mathrm{Fe}^{3+}$, namely melanterite and epsomite. $\mathrm{Fe}^{3+}$ can be found in all the alterations of the carbonates, which lends a characteristic red/orange hue.

- Each weathering test of EN 12326:2005 reveals a different type of alteration. The thermal cycle uses a heating/hydration process to act upon the iron sulfides' proneness to oxidation, favoring the change from $\mathrm{Fe}^{2+}$ to $\mathrm{Fe}^{3+}$. The response to this test depends largely on the mineralogy of these iron sulfides, pyrrhotite being more weatherable than pyrite.

- The test for exposure to $\mathrm{SO}_{2}$ mainly attacks carbonates, which transform into gypsum, and in turn increase in size and affect the cohesion of the slate by encouraging the detachment and fragmentation of the tile. Iron sulfides are also affected by this test, although the typology of the changes differs from that of the thermal cycle test.

- There are other standard tests that can be used alongside those described in EN 12326:2005. Ageing by salt mist (EN 14147:2004) affects iron sulfides by creating a saline environment with a high background electrolyte that favors the $\mathrm{Fe}^{2+}$ to $\mathrm{Fe}^{3+}$ reaction. Alterations produced in this test usually cover a larger area than those produced during thermal cycles, though they lack the same intensity. Exposure to UV rays (EN 11507:2007) reveals the slates' potential to change color.

- Evaluation of the potential weathering of roofing slates can be determined by using a combination of these tests, which affect only the alterable minerals that are to be found in slate. Furthermore, the alterations produced in these tests can be truly quantified using image analysis, which is a more objective method than the visual assessment currently used in the standards.

\section{ACKNOWLEDGEMENTS}

This study has been carried out as part of the project "PERDURABLE: Durability of natural stone materials. Analysis and prevention of pathologies. MICINN-09-CIT-380000-200925 , "financed by the Spanish Ministry of Science and Innovation. Thanks also to the Slate Technology Center Foundation (FCTP), in Sobradelo de Valdeorras, to its manager Cristina Álvarez for her help in conducting the standard tests and to Nicholas Callaway for his critical review of the manuscript. 


\section{BIBLIOGRAFÍA / BIBLIOGRAPHY}

(1) Cárdenes, V.; García-Guinea, J.; Monterroso, C.; de la Horra, R.: "Protocol for assessing the effectiveness of protective coatings for roofing slate", Materiales de Construcción, vol. 58 (2008), pp. 263-79.

(2) Rivas, T.; Iglesias, J.; Cañas, I.; Cárdenes, V.; Tabeada, J.: "Oxidación de sulfuros en pizarra ornamental: Tratamientos protectores con siloxanos", Conferencia Internacional Minería Sostenible (15, 16, 17 de abril de 2009), Santiago de Compostela.

(3) García-Guinea, J.; Cárdenes, V.; Lombardero, M.; Desiloniz, M.: "Determinación de sulfuros de hierro en pizarras para cubiertas del noroeste de España", Materiales de Construcción, vol. 52, no 266 (2002), pp. 55-63.

(4) SIEMCALSA: "Reestructuración de Escombreras en San Pedro de Trones (León)", Ordenación Sector Pizarra. Fase I 1999.

(5) SIEMCALSA: "Reestructuración de explotaciones en La Baña, Ordenación de la minería de la pizarra" (2002).

(6) ICOMOS: "Illustrated glossary on stone deterioration patterns", ICOMOS International Scientific Committee for Stone (ISCS) (2008).

(7) Silva, B.; Prieto, B.; Rivas, T.; Pereira, L.: "Origen y efectos deteriorantes del yeso en monumentos graníticos del noroeste de España", Materiales de Construcción, vol. 60, no 297 (2010), pp. 97-110. doi: 10.3989/mc.2010.46808

(8) Ruiz de Argandeña, V. G.; Calleja, L.; Suárez Del Río, L. M.; Rodríguez-Rey, A.: "Durabilidad de rocas pizarrosas del Valle del Huerna (Asturias)", Boletín Geológico y Minero, vol. 105, no 2 (1994), pp. 204-12.

(9) Belzile, N.; Chen, Y. W.; Cai, M.; Li, Y.: "A review on pyrrhotite oxidation", Journal of Geochemical Exploration, vol. 84, no (2004), pp. 65-76.

(10) Evangelou, V. P.: "Pyrite Oxidation and Its Control: Solution Chemistry, Surface Chemistry, Acid Mine Drainage", CRC Press, (1995).

(11) Gómez-Fernández, F.; Castaño, M. A.; Bauluz, B.; Ward, C.: "Optical microscope and SEM evaluation of roofing slate fissility and durability", Materiales de Construcción, vol. 59, no 296 (2009), pp. 93-106. doi: 10.3989/mc.2009.44007

(12) Gutiérrez-Marco, J. C.; Aramburu, C.; Arbizu, M.; Bernárdez, E.; Hacar, M.; Méndez-Bedia, I.; Montesinos, R.; Rábano, I.; Truyols, J.; Villa, E.: "Revisión bioestratigráfica de las pizarras del Ordovícico Medio en el Noroeste de España (Zonas Cantábrica, Asturoccidental - Leonesa y Centroibérica septentrional)", Acta Geológica Hispana, vol. 34, no (1999), pp. 3-87.

(13) Fischer, C.; Karius, V.; Thiel, V.: "Organic matter in black slate shows oxidative degradation within only a few decades", Journal of Sedimentary Research, vol. 77, no (2007), pp. 355-65.

(14) Fischer, C.; Schmidt, C.; Bauer, A.: "Mineralogical and geochemical alteration of low-grade metamorphic black slates due to oxidative weathering", Chemie der Erde, vol. 69, no (2009), pp. 127-142.

(15) Ward, C.; Gómez-Fernández, F.: "Quantitative mineralogical analisis of Spanish roofing slates using the Rielveld method and X-ray powder diffraction data", European Journal of Mineralogy, vol. 15 (2003), pp. 1051-1662. http://dx.doi.org/10.1127/0935-1221/2003/0015-1051 (16) Cárdenes, V.; De la Horra, R.; Monterroso, C.; García-Guinea, J.; País, V.: "Depósitos de pizarras para cubiertas en la Península Ibérica", VII Congreso Geológico de España, Las Palmas de Gran Canaria, 2008. p. 453.

(17) García-Guinea, J.; Lombardero, M.; Roberts, B.; Taboada, J.: "Spanish Roofing Slate Deposits", Transactions of the Institute of Mineral Metallurgy, Section B, vol. 106, nº (1997), pp. 205-214.

(18) Barrois, C.: "Recherches sur les terrains anciens des Asturies et la Galicie", Mémoires de la Société Géologique du Nord de la France, vol. 2, no 1 (1882).

(19) Barros, J. C.: "Nuevos datos geológicos y cartográficos sobre el flanco Sur del Sinclinorio de Truchas", Cuadernos do Laboratorio Xeolóxico de Laxe, vol. 14, no (1989), pp. 93-116.

(20) UNE-EN 12326-1:2005: "Productos de pizarra y piedra natural para tejados y revestimientos discontinuos. Parte 1 (Especificación de producto) y Parte 2 (Métodos de ensayo)", AENOR, Madrid (2005).

(21) Blanchard, I. G.; Sims, I.: "European testing of roofing slate", Construction Materials, vol. 160, no (2007), pp. 1-6.

(22) C 217-94: "Standard Test Method for Weather Resistance of Slate", ASTM (1999), p. 3.

(23) UNE-EN 14147:2004. "Métodos de ensayo para la piedra natural. Determinación de la resistencia al envejecimiento por niebla salina", AENOR, Madrid (2004), p. 12.

(24) UNE-EN 11507:2007: "Pinturas y barnices. Exposición de los recubrimientos a envejecimiento artificial. Exposición a lámparas de UV fluorescente y al agua" (2007), AENOR, p. 18.

(25) Berns, R. S.: "Billmeyer and Saltzman's Principles of Color Technology", Willey Interscience (2000).

(26) Sanmartín, P.; Ferrer, P.; Cárdenes, V.; Martínez-Verdú, F. M.; Silva, B.; Prieto, B.: "El color de las rocas ornamentales: Comparación de las metodologías de determinación en granitos y pizarras", IX Congreso Nacional del Color, Alicante (2010), pp. 433-36.

(27) UNE-EN ISO 105-A05:1997: "Evaluación instrumental de la degradación para la determinación del índice de la escala de grises", AENOR (1997), p. 8.

(28) UNE-EN ISO 105-J03:2010: "Cálculo de diferencias de color", AENOR (2010), p. 15.

(29) Abramoff, M. D.; Magelhaes, P. J.; Ram, S. J.: "Image processing with ImageJ", Biophotonics International, vol. 11, no 7 (2004), pp. 36-42.

(30) Gómez-Fernández, F.; Ward, C.; Bauluz, B.: "XRD, electron microscopy (EMPA, SEM, TEM) and XRF characterization of roofing slates from NW Spain", Cuadernos do Laboratorio Xeolóxico de Laxe, vol. 34 (2009), pp. 127-142.

(31) Wagner, W.; Baumann, H.; Negedank, J.; Roschig, F.: "Geological, petrographic, geochemical and petrophysical investigations on roofing slates. Mainzer Geowissenschaftliche Mitteilungen", Geological Survey of Rheinland-Pfalz (1997).

$$
* * *
$$

